\title{
Efficacy of $4 \%$ articaine vs $2 \%$ lidocaine in mandibular and maxillary block and infiltration anaesthesia in patients with irreversible pulpitis: a systematic review and meta-analysis
}

\author{
Sanjay Miglani ${ }^{1}$, Irfan Ansari $^{1}$, Swadheena Patro ${ }^{2}$, Ankita Mohanty $^{2}$, Shahnaz Mansoori ${ }^{3}$, Bhoomika Ahuja ${ }^{4}$,

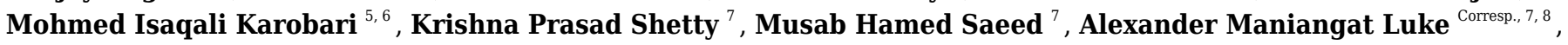 \\ Ajinkya M Pawar ${ }^{\text {Corresp. } 9}$ \\ ${ }^{1}$ Department of Conservative Dentistry \& Endodontics, Faculty of Dentistry, Jamia Millia Islamia (a central University), Okhla, New Delhi, Delhi 110025, \\ India., Delhi, India \\ 2 Department of Conservative Dentistry \& Endodontics, Kalinga Institute of Dental Sciences, Bhubaneswar 751024, Odisha, India, Bhubaneswar, India \\ 3 Department of Public Health, Faculty of Dentistry, Jamia Millia Islamia (a central University), Okhla, New Delhi, Delhi 110025, India, Delhi, India \\ 4 Department of Paediatric Dentistry, K D Dental College, Mathura 281121, Uttar Pardesh, India, Mathura, India \\ 5 Conservative Dentistry Unit, School of Dental Sciences, Universiti Sains Malaysia, Health Campus, Kubang Kerian 16150, Kota Bharu, Kelantan, Malaysia, \\ Kota Bharu, Malaysia \\ 6 Department of Conservative Dentistry \& Endodontics, Saveetha Dental College \& Hospitals, Saveetha Institute of Medical and Technical Sciences \\ University, Chennai, Tamil Nadu, India \\ 7 Department of Clinical Science, College of Dentistry, Ajman University, Al-Jurf Ajman UAE., Al-Jurf Ajman, UAE \\ 8 Centre of Medical and Bio-allied Health Sciences Research, Ajman University, Ajman, UAE., Ajman, UAE \\ 9 Department of Conservative Dentistry \& Endodontics, Nair hospital Dental College, Mumbai 400008, Maharashtra, India, Mumbai, India
}

Corresponding Authors: Alexander Maniangat Luke, Ajinkya M Pawar

Email address: a.luke@ajman.ac.ae, ajinkya@drpawars.com

Objective: The goal of this systematic review and meta-analysis is to determine the performance of $4 \%$ Articaine vs. $2 \%$ Lidocaine for mandibular and maxillary block and infiltration anaesthesia in patients with irreversible pulpitis (IP). Methods:

PubMed/MEDLINE, Cochrane Central Register of Controlled Trials, Web of Science, Google Scholar, and Open Gray were used to conduct a thorough literature search. A manual search of the reference lists of the publications found was also carried out. Two reviewers critically evaluated the papers for inclusion and exclusion criteria, and data extraction was done on the selected publications. The Cochrane Collaboration Tool and the Minors checklist were used to assess the quality of the selected studies for randomised controlled trials (RCTs) and non-randomised studies, respectively. The RevMan software was used to perform a meta-analysis of the pooled data and subgroups according to the technique of anaesthetic solution delivery, as well as a sensitivity analysis $(P<0.05)$. Results: A total of twenty-six papers were included in the qualitative synthesis, with twenty-two of them being included in the meta-analysis. There were fifteen studies with a low potential for bias, three with a moderate potential for bias, and seven with a high potential for bias. The combined results of the 19 trials in the tooth level unit revealed that $4 \%$ articaine had a 
success rate 1.37 times greater than $2 \%$ lidocaine for mandibular teeth $(\mathrm{RR}, 1.37 ; 95 \% \mathrm{Cl}$, 1.17 to $1.62 ; \mathrm{P}=0.0002$ ). For the maxillary buccal infiltration method, the combined results from the three trials revealed that $4 \%$ articaine resulted in a success rate 1.06 times greater than $2 \%$ lidocaine ( $R R, 1.06 ; 95 \% \mathrm{Cl}, 0.95$ to $1.2 ; \mathrm{P}=0.3$ ). Excluding subgroups with a single study in sensitivity analysis for mandibular teeth revealed a substantial improvement in the success rate of the articaine group in treating IP when compared to the lidocaine group. Conclusion: The findings of this meta-analysis back up the claim that articaine is more effective than lidocaine in providing anaesthesia in patients with IP. 
1 Title

2 Efficacy of $4 \%$ articaine vs $2 \%$ lidocaine in mandibular and maxillary block and infiltration

3 anaesthesia in patients with irreversible pulpitis: a systematic review and meta-analysis

4 Abstract

5 Objective: The goal of this systematic review and meta-analysis is to determine the performance

6 of 4\% Articaine vs. 2\% Lidocaine for mandibular and maxillary block and infiltration anaesthesia

7 in patients with irreversible pulpitis (IP).

8 Methods: PubMed/MEDLINE, Cochrane Central Register of Controlled Trials, Web of Science,

9 Google Scholar, and Open Gray were used to conduct a thorough literature search. A manual

10 search of the reference lists of the publications found was also carried out. Two reviewers critically

11 evaluated the papers for inclusion and exclusion criteria, and data extraction was done on the

12 selected publications. The Cochrane Collaboration Tool and the Minors checklist were used to

13 assess the quality of the selected studies for randomised controlled trials (RCTs) and non-

14 randomised studies, respectively. The RevMan software was used to perform a meta-analysis of

15 the pooled data and subgroups according to the technique of anaesthetic solution delivery, as well

16 as a sensitivity analysis $(\mathrm{P}<0.05)$.

17 Results: A total of twenty-six papers were included in the qualitative synthesis, with twenty-two

18 of them being included in the meta-analysis. There were fifteen studies with a low potential for

19 bias, three with a moderate potential for bias, and seven with a high potential for bias. The

20 combined results of the 19 trials in the tooth level unit revealed that $4 \%$ articaine had a success

21 rate 1.37 times greater than $2 \%$ lidocaine for mandibular teeth $(\mathrm{RR}, 1.37 ; 95 \% \mathrm{CI}, 1.17$ to $1.62 ; \mathrm{P}$

$22=0.0002$ ). For the maxillary buccal infiltration method, the combined results from the three trials

23 revealed that $4 \%$ articaine resulted in a success rate 1.06 times greater than $2 \%$ lidocaine (RR, 
$241.06 ; 95 \% \mathrm{CI}, 0.95$ to $1.2 ; \mathrm{P}=0.3)$. Excluding subgroups with a single study in sensitivity analysis

25 for mandibular teeth revealed a substantial improvement in the success rate of the articaine group

26 in treating IP when compared to the lidocaine group.

27 Conclusion: The findings of this meta-analysis back up the claim that articaine is more effective 28 than lidocaine in providing anaesthesia in patients with IP.

29 PROSPERO Registration No.: CRD42020204606

30 (https://www.crd.york.ac.uk/prospero/display record.php?ID=CRD42020204606)

31

Key words: Articaine, irreversible pulpitis, lidocaine, meta-analysis, sensitivity analysis, success rate

\section{Introduction}

Dental caries is the most widespread non-communicable disease and a major public health concern globally. It is also the most common preventable disease, recognised as the primary cause of oral pain and tooth loss (1). Pulpitis is the inflammation of the dental pulp and a sequel to caries. It is clinically classified as reversible or irreversible (2). Irreversible pulpitis (IP), usually develops when the pulp is exposed to caries biofilm causing necrosis or death of pulp tissues, indicating the need for endodontic treatment $(3,4)$.

Successful anaesthesia is a hallmark of painless endodontic treatment. It not only keeps the patient calm and relaxed but also allows the dentist to perform the endodontic procedure with ease $(5,6)$. Pulpal anaesthesia commences with the administration of traditional nerve blocks (NBs) or infiltration anaesthesia. For maxillary teeth, NB injections are administered at the anterior superior alveolar (ASA), middle superior alveolar (MSA), and/or posterior superior alveolar (PSA) nerves. For mandibular anterior teeth and molars, both the inferior alveolar nerve block (IANB) and buccal 
48 infiltration (BI) injections are administered (7). Local anaesthetic (LA) drugs have a peripheral

49 effect and block the transmission of nerve impulses. Factors that affect anaesthetic drug efficacy

50 are the type of applied drug, correct injection site, injection velocity, and amount and dosage of

51 the injected drug. Also, the presence of inflammation at the injection site should not be overlooked $52(8)$

53 The success rate of achieving deep pulpal anaesthesia lowers in patients with IP. The success rate

54 of IANB can be reduced to $<30 \%$ (9), and that of maxillary NBs to $<60 \%$ (10). It is broadly

55 accepted that achieving anaesthesia in patients with IP is more complex, as compared to normal,

56 healthy pulps $(11,12)$. Inflamed pulp shows lower $\mathrm{pH}$ levels, lowering the penetration of basic

57 anaesthetic into the nerve membrane, thus delaying or preventing pulpal anaesthesia (4). This state

58 of the tooth is frequently referred to as a 'hot pulp', which requires supplementary approaches to

59 ensure a pain-free treatment (5). Nonetheless, the effect of different anaesthetic agents and

60 techniques along with or without supplemental infiltration needs to be assessed.

61 Lidocaine, the first commercialised amide LA solution shows rapid onset when used for most of

62 the dental treatments and is considered as the gold standard LA agent due to its high efficacy, low

63 allergenicity and minimal toxicity (13). Articaine [(4-methyl-3-[1-oxo-2-(propylamino)-

64 propionamido]-2-thiophene-carboxylic acid methyl ester hydrochloride)] is a unique amide LA

65 agent that contains a thiophene ring instead of a benzene ring, demonstrating increased

66 liposolubility and high tissue penetrability as compared to lignocaine. The thiophene ring raises

67 the diffusion of the anaesthetic solution into the cortical bone, thereby penetrating the mandibular

68 dense cortical bone as well as maxillary cortical plates. Previous studies by de Geus et al (14) and

69 Srinivasan MR et al (15) have also shown that articaine is equally effective in comparison to other

70 anaesthetics with the success rate ranging from 64 to $87 \%$. 
71 Systematic reviews comparing the anaesthetic efficacy of articaine and lidocaine for dental

72 procedures have been published. Kung et al concluded that articaine has a significant advantage

73 over lidocaine as a supplementary infiltration after mandibular block anaesthesia but no advantage

74 when used alone as mandibular block or maxillary infiltration anaesthesia (16). Su et al stated that

75 at the injection phase and treatment phase, $4 \%$ articaine is superior in controlling pain and

76 increasing the success rate of local anaesthesia than $2 \%$ lidocaine (13). However, out of 24 articles

77 included in that analysis, 20 articles were Chinese language reports which could not be accessed

78 and retrieved from the databases by the authors of this review. Both the reviews described above

79 were based on searches conducted until 2013. de Geus et al in the network meta-analysis concluded

80 that in patients with IP, the use of articaine increased the IANB success rate. This review

81 considered the efficacy of IANB in patients with IP and did not include maxillary injection

82 techniques as well as other supplemental techniques (14). A preliminary electronic database search

83 revealed that since the publication of the above reviews, several new randomised clinical trials

84 (RCTs) comparing articaine and lidocaine for patients with symptomatic IP have been published.

85 Therefore, the present systematic review assessed the efficacy of $4 \%$ articaine $v_{s} 2 \%$ lidocaine in

86 the mandibular and maxillary block and infiltration anaesthesia in patients with IP.

88 Methods

89 Protocol development

90 This systematic review and meta-analysis are written and reported according to the Preferred

91 Reporting Items for Systematic Review and Meta-Analyses (PRISMA) statement and registered

92 in PROSPERO (CRD42020204606). The following focused question in the Patient, Intervention,

93 Comparison, and Outcome (PICO) format was proposed "Is there a difference in the efficacy of 
$944 \%$ articaine vs $2 \%$ lidocaine in the mandibular and maxillary block and infiltration anaesthesia in 95 patients with IP?"

99 Search Strategy

100 To obtain publications in the English language, a complete electronic search was conducted

101 through July 2020 on databases such as PubMed and MEDLINE, Cochrane Central Register of

102 Controlled Trials, and Web of Science. A detailed electronic search of the journals listed in Table

1031 was carried out.The searches in the clinical trials database, cross-referencing and Grey literature

104 were conducted using Google Scholar, Greylist, and OpenGrey.

105

106 Articles were found using Medical Subject Headings (MeSH) terms, keywords, and other free 107 terms coupled with Boolean operators (OR, AND). Following the syntactic guidelines of each 108 database, the same terms were utilised across all search platforms. Table 1 shows the search 109 strategy, population, interventions, comparisons, outcomes, and study design (PICOS) tool.

\section{Inclusion criteria outline according to the PICOS strategy}

112 Population $(\mathrm{P})$ :

113 Studies on patients with symptomatic IP, requiring endodontic treatment under maxillary and

114 mandibular infiltration or blocked anaesthesia on at least one tooth in the mandibular or maxillary

115 region irrespective of age, gender, race, or socioeconomic status, were evaluated. Active responses 
116 to spontaneous pain, thermal tester, cold tester, or an electronic pulp tester were considered as

117 diagnostic criteria for IP.

118 Interventions (I): Studies using 4\% articaine as a LA solution for the treatment of IP.

119 Comparison (C): Studies using 2\% lidocaine as a LA solution for the treatment of IP.

120 Outcome $(\mathrm{O})$ : Primary outcome: It included the success rate assessed as 'no/mild' pain during

121 access cavity preparation and biomechanical preparation phase on the Heft Parker visual analogue 122 scale (VAS).

123 Secondary outcome: Onset of anaesthesia assessed from the time lapse between the end of the NB

124 and the onset of symptoms of subjective anaesthesia (feeling of heaviness at the site of injection)

125 were calculated in seconds, and the pain was assessed quantitatively during the treatment.

126 Study design (S): In vivo studies, clinical trials, RCTs, cluster randomised trials, quasi127 experimental studies and non-randomised trials (NRS).

\section{Exclusion criteria}

130 - Studies involving patients with a significant medical history or on medicaments that may affect

131 the anaesthetic assessment.

132 - Observational study designs, case reports, case series, cross-sectional studies, and reviews.

133 - Trials reporting a single intervention.

134 - Article reporting only abstracts and full-texts were not available in the database.

\section{Screening process}

137 Two reviewing authors did the search and screening according to the previously stated 138 methodology (SP \& AM). The titles and abstracts were examined first. Second, full-text 
139 publications were picked for in-depth reading and analysis based on the data extraction criterion's

140 inclusion and exclusion criteria. Cohen's kappa $(\mathrm{k})$ determined the degree of agreement between

141 the two reviewers to be 0.94 for titles and abstracts and 0.96 for full-texts. After discussions, the

142 third author (SM) was able to reconcile the disagreements among the authors/reviewers. The

143 authors of the listed papers were contacted via email for clarification of any concerns or missing

144 data.

\section{Data extraction}

148 The two independent authors (IA \& BA) extracted the following data from the included studies:

149 author names, study design, tooth, sample size, method of pulp testing, type of local anaesthesia

150 used, injection technique, method of analysis, method of outcome assessment, follow-up and

151 author's conclusions.

\section{Assessments of the risk of bias and quality}

153 The level of evidence for included studies was assessed using the Joanna Briggs Institute (JBI) level

154 of evidence (17). The quality of the selected studies was assessed using the Cochrane Collaboration

155 Tool (18) for RCTs, including random sequence generation, allocation concealment, blinding of

156 participants, incomplete outcome data, selective reporting, and other biases. The quality of NRS was

157 assessed using the Minors checklist (19), wherein the minimum outcome assessment time of 5 min

158 was considered appropriate for the included studies.

\section{Statistical analysis}

160 Review Manager (RevMan) 5.3 was used for statistical analysis. The combined results were

161 expressed as relative risks (RRs) for the dichotomous data at 95\% confidence intervals (CIs) and 
$162 \mathrm{P}<0.05$ was considered significant. Statistical heterogeneity was assessed by the $\mathrm{I}^{2}$ test at $\alpha=0.10$.

163 Subgroup analysis was conducted for $\mathrm{I}^{2}>50 \%$ and $\mathrm{P} \leq 0.10$. For $\mathrm{I}^{2}>50 \%$, the random-effects model

164 was applied. Sensitivity analysis was conducted to assess the stability of the results. Funnel plots

165 were drawn to detect publication bias for studies exceeding 10 in number for each outcome 166 assessed (13).

167 Results

168 Literature search

169 The PRISMA statement flowchart summarising the selection process is presented in Figure 1.

170 Among 33 full-text articles, 26 were selected after pre-screening, applying the eligibility criteria,

171 and addressing the PICOS question. Seven studies were excluded as 3 did not have a control group,

1723 had inappropriate population variables, and 1 applied intraosseous injection technique, hence

173 only 26 studies were included in the qualitative analysis, whereas 22 out of 26 studies for

174 quantitative synthesis.

175

176 Study characteristics:

177 The general characteristics of 26 studies (20-45) are presented in Table 2. All included studies

178 were unicentric trials published between 2011 and 2020. Of the 26 studies, 10 studies

$179(21,22,24,27,28,31,38,43-45)$ were conducted in different parts of India, 3 in Iran $(23,30,39)$,

180 Pakistan $(32,34,36)$ and Brazil $(29,33,40), 2$ in the USA $(26,37), 2$ in the UK( 41,42$)$ and one

181 each in China (20), Colombia (25) and Saudi Arabia (35). The study design of 24 studies (20-34,

182 36-42, 44, 45) was RCTs, and the remaining 2 studies $(35,43)$ were NRS. The age of the

183 participants was 15-65 years. The ethical clearance and informed consent were obtained in all

184 except 2 studies $(24,43)$. A total of 1824 teeth with completely formed root apex, diagnosed with 
185 symptomatic IP and anaesthetised with either articaine or lidocaine were included in the review,

1861578 mandibular teeth from 22 studies (20-29,32-35,37-40,42-45) and 246 maxillary teeth from 4

187 studies comprised the present meta-analysis $(30,31,36,41)$ (Table 2).

188

189 A significant methodological heterogeneity was observed between the studies. This could be

190 attributed due to the differences in the anatomic location of the teeth being anaesthetized [mandible

$191(20-29,32-35,37-40,42-45)$ or maxilla $(30,31,36,41)$, anterior $(31,41,42)$ or posterior $(20-45))$,

192 tooth type (molars $(20-30,32-45)$, premolars $(31,36,41,42)$ or anterior teeth $(31,41,42)]$, volume of

193 anaesthetic solution administered during the intervention [0.6 mL (22), $0.9 \mathrm{~mL}(20), 1.7 \mathrm{~mL}$

$194(26,34,36,37,43), 1.8 \mathrm{~mL}(21,25,27,30,32,33,38-40,44,45), 2.0 \mathrm{~mL}(24,31,41,42), 3 \mathrm{~mL}(28), 3.6$

$195 \mathrm{~mL}(29)$ and $6 \mathrm{~mL}(28)]$, concentration of epinephrine in articaine and lidocaine and delivery route

196 of the anaesthetic solution. Interestingly, the anaesthetic solutions for mandibular teeth were

197 delivered via IANB $(21,23,25,27-29,35,38,40,45)$, BI $(30,32-34,36,43,45)$, supplementary BI after

198 IANB failure $(20,26,37,42)$, BI combined with intraligamentary injection (24), supplementary

199 intraligamentary injections after IANB failure (22), standard IANB and long Bis (39) and IANB

200 plus BI (44) and for maxillary teeth via BI (41), anterior middle superior alveolar nerve block

201 (AMSA) (31) and infraorbital nerve block (IONB) (31). In nineteen studies, both the anaesthetic

202 solutions were administered by the same dentist. $(20,21,23,25-32,35,37-39,41,42,44,45)$ (Table 2).

203

204 The outcome parameters assessed post-intervention varied across studies. The success of pulpal

205 anaesthesia assessed by VAS on a 4-point Likert scale or on a measured scale as no/mild pain

206 during root canal treatment (endodontic access and pulpectomy) after administration of local

207 anaesthesia, whereas the postoperative pain was assessed by the corresponding pain score on the 
208 numerical scale $(26,31,32,37,43)$. The onset of anaesthesia was assessed from the time lapse

209 between the end of NB and the onset of symptoms of subjective anaesthesia, such as the feeling

210 of heaviness at the site of injection and lip numbness, or by electric pulp testing, cold testing, pulp

211 evaluation and canal preparation using a standard digital stop clock. For the mandibular region, 19

212 studies assessed the success rate of anaesthesia (20-22,23-27,29,32-35,37-39,42-45), 4 studies

213 evaluated the postoperative pain $(28,32,37,44)$ and 1 study evaluated the mean onset time of

214 anaesthesia (40). For the maxillary region, the success rate of anaesthesia was reported by 3 studies

$215(30,36,41), 1$ study (31) reported postoperative pain and 2 studies reported $(31,41)$ the mean onset

216 time of anaesthesia. The recording time after LA injection ranged from 5-30 min in all the included

217 studies, except in one (28), which did not mention the time. VAS was used to assess the outcome

218 in all studies except that the verbal analogue scale was applied by Allegretti et al. (29) and the

219 study by Tortamano et al. (40) calculated the onset of pulpal anaesthesia in minutes. Overall, post-

220 intervention results showed improvements in the intervention groups based on the outcome

221 parameters $(20,21,23-28,30-42,44,45)$.

222

223 The mandibular postoperative pain assessed by Ghazalgoo et al. (23), Umesh et al. (28), Zain et al.

224 (32), Rogers et al. (37) and Aggarwal et al. (44) using Heft Parker VAS did not show a statistically 225 significant difference between the two groups. The time point for outcome measurement and the 226 outcomes of interest, based on the scoring criteria, were different; also, the method of delivery of 227 the anaesthetic solution varied in each of the included studies. Thus, these were precluded from 228 the meta-analysis, and only qualitative analysis was conducted (Table 2). 229 
230 The study by Saraf et al. (31) concluded that 4\% articaine was more efficacious than $2 \%$ lidocaine,

231 and AMSANB was more beneficial than IONB in achieving the anaesthetic effect of maxillary

232 anterior teeth and premolars. It was a single study included for assessing the postoperative pain

233 using the visual analogue scale and the onset time of anaesthesia for maxillary teeth and was not

234 considered for qualitative synthesis. The onset time of anaesthesia for mandibular teeth was

235 assessed by Tortamano et al. (40) and concluded that 4\% articaine exhibited rapid onset with the

236 highest duration of pulpal anaesthesia in IANB. However, since this was a single study, it was not

237 considered for quantitative synthesis (Table 2).

238

239 Assessments of the level of evidence, risk of bias, and quality:

240 According to JBI level of evidence, 21 studies $(20-23,25-30,32-34,36-39,41,42,44,45)$ were

241 ranked at $1 \mathrm{c}$ and the remaining 5 studies $(24,31,35,40,43)$ as $1 \mathrm{~d}$.

243 The quality assessment of 11 RCTs was executed according to the Cochrane Risk of Bias Tool

244 (20-34,36-42,44,45). Moreover, 13 studies (20,22,25-30,33,37,39,41,44,45) showed a low

245 potential risk of bias, $3(21,33,38)$ presented a moderate risk and $7(24,31,32,34,36,40,42)$ had a

246 high potential risk of bias (Figure 2).

247

248 MINORS was used for quality assessment of 2 non-randomised comparative studies $(35,43)$ that 249 presented a score of 21 (Table 3 ). Only 5/26 studies $(30,35,37,39,45)$ disclosed receiving financial 250 support for the work.

251

252 Synthesis of results: 
253 A total of 22 studies (20-22,24-27,29,30,32-45) fulfilled the inclusion criteria for quantitative

254 analysis. Subsequently, two meta-analyses, including one subgroup analysis, were performed on

255 the success rate of anaesthesia for mandibular and maxillary teeth.

256

257 The success rate of anaesthesia for mandibular teeth:

258 The pooled outcomes from 19 studies, in tooth level unit, using random-effect model showed that $2594 \%$ articaine resulted in a success rate 1.37 -fold higher than that of $2 \%$ lidocaine (RR, $1.37 ; 95 \%$

260 CI: $1.17-1.62 ; \mathrm{P}=0.0002)$, showing statistically significant difference favouring the articaine group

261 and $72 \%$ heterogeneity $\left(\mathrm{I}^{2}\right)$. When subgroup analysis was performed according to the injection

262 techniques using random-effect model, it was observed that for IANB $(21,25,27,29,35,38,45), 4 \%$

263 articaine resulted in a success rate 1.25 -fold higher than that for $2 \%$ lidocaine (RR, $1.25 ; 95 \% \mathrm{CI}$ :

$2640.98-1.59 ; \mathrm{P}=0.007$ ) showing statistically significant difference favouring the articaine group with

$26543 \%$ heterogeneity. For BI technique $(21,32-34,42,45), 4 \%$ articaine resulted in a success rate $1.13-$

266 fold higher than that for $2 \%$ lidocaine (RR, $1.13 ; 95 \%$ CI: $0.89-1.45 ; \mathrm{P}=0.31$ ) with $68 \%$

267 heterogeneity. Supplementary BI after IANB failure technique $(20,26,37,42)$ showed that $4 \%$

268 articaine resulted in a success rate of 1.53 -fold higher than $2 \%$ lidocaine (RR, $1.53 ; 95 \%$ CI: $1.821-$

269 1.94; $\mathrm{P}=0.0004$ ) showing statistically significant difference favouring the articaine group with the

270 heterogeneity of $36 \%\left(\mathrm{I}^{2}\right)$. BI combined with intraligamentary injection technique ${ }^{24}$ showed that

$2714 \%$ articaine resulted in a success rate of 8.33 -fold higher than that for $2 \%$ lidocaine (RR, 8.33;

272 95\% CI: 2.81-24.67; $\mathrm{P}=0.0001$ ) showing statistically significant difference favouring the articaine

273 group. For supplementary intraligamentary injections after IANB failure (22) and standard IANB

274 and long BI technique (39), 4\% articaine resulted in a success rate 0.9 -fold (RR, 0.9; 95\% CI:

275 0.67-1.2; $\mathrm{P}=0.47)$ and 2.41-fold $(\mathrm{RR}, 2.41 ; 95 \% \mathrm{CI}: 1.56-1.2 ; \mathrm{P}<0.0001)$ higher than that of $2 \%$ 
276 lidocaine, respectively showing statistically significant difference favouring the articaine group

277 for standard IANB and long BI technique but not for supplementary intraligamentary injections

278 after IANB failure. For IANB plus BI technique (44), 4\% articaine resulted in a success rate of

279 1.38-fold higher than that for $2 \%$ lidocaine $(\mathrm{RR}, 1.38 ; 95 \%$ CI: $0.74-2.6 ; \mathrm{P}<0.0001)$ showing a

280 statistically significant difference favouring the articaine group (Figure 3).

281

282 The success rate of anaesthesia for maxillary teeth:

283 The pooled outcomes from 3 studies $(30,36,41)$ on tooth level unit for maxillary buccal infiltration

284 technique showed that $4 \%$ articaine resulted in a success rate of 1.06 -fold higher than that for $2 \%$

285 lidocaine (RR, 1.06; 95\% CI: $0.95-1.2 ; \mathrm{P}=0.3, \mathrm{I}^{2}=0 \%$ ) using random-effects model, showing 286 statistically insignificant difference (Figure 4).

287

288 Sensitivity analysis:

289 Table 4 represents the results of sensitivity analysis for mandibular teeth. Studies of high risk $290(24,31,32,34,36,40,42)$, moderate risk $(21,33,38)$ or low risk of bias $(20-34-45)$ were excluded 291 from sensitivity analysis. The clinical success rates comparing the articaine and lidocaine groups 292 showed a significant change after the exclusion of these studies. Reanalysis using the fixed-effect 293 model also showed that the outcomes were not adverse. The exclusion of subgroups with a single 294 study showed a significant improvement in the success rate of articaine group as compared to the 295 lidocaine group in the treatment of IP. Moreover, the subgroup analysis for different injection 296 techniques showed a significant change after the inclusion of only supplementary BI after IANB 297 failure technique as compared to the inclusion of IANB and BI technique (Table 4). 
299 Publication bias for studies included on mandibular anaesthetic technique was evaluated using a

300 funnel plot (Figure 5). The funnel plot showed asymmetry at the apex from the centre line having

301 more studies on the right side as compared to left, representing a lack of inclusion of publications

302 describing non-significant intervention results as well as the omission of unpublished studies that

303 might result in an over-estimation of the true effect of an intervention.

\section{Discussion}

Endodontic pain management is a critical component in reducing extreme anxiety during endodontic treatment. LA's in-depth and methodical expertise, as well as its suitable delivery methodologies, are essential for pain-free dental treatment (44). The gold standard amide anaesthetic, lidocaine, has a brief start of action, but when combined with epinephrine, the duration

311 of action increases to intermediate (23). In patients with endodontic discomfort, the success of

312 lidocaine in IANB and infiltration remains low $(44,46,47)$. The risk of failed local anaesthetic was

313 eight times greater in patients with IP than in normal individuals (47). Pain is initially transmitted

314 by A-delta and C-fibres in IP, but as the inflammatory process advances, C-fibre transmission

315 takes over, resulting in changed pain characteristics. Strong, quick, acute, and well-localized pain

316 is caused by A-delta fibres, whereas dull, persistent, and radiating pain is caused by C-fibres (48).

317 Anatomical causes, acute tachyphylaxis, and the influence of inflammation on local tissue

$318 \mathrm{pH}$, blood flow, nociceptors, central sensitization, and psychological variables are all possible

319 reasons for failure (44-47). Articaine is more effective in reducing the action potential produced

320 by A-fibres as compared to $2 \%$ lidocaine and the complete disappearance of the action potential

321 produced by C-fibres (29) (Figure 6). 
323 evaluating the efficacy of $4 \%$ articaine and $2 \%$ lidocaine in the mandibular and maxillary block

324 and infiltration anaesthesia in patients with IP, according to the Oxford Centre for Evidence-based

325 Medicine's levels of evidence criteria (49). The review included 26 research published between

3262011 and 2020 in various countries ( 24 randomised trials and 2 non-randomised trials). The study

327 participants ranged in age from 15 to 65 years old and were of both genders. Therefore, the findings

328 of this systematic review may be applied to a wide variety of people, as well as anaesthetic

329 effectiveness in mandibular and maxillary teeth with symptomatic IP. Pulp sensitivity tests and the

330 exclusion of periapical diseases were used to determine if research subjects met the criteria for

331 symptomatic IP in the included studies. Participants who have been taking any medication that

332 may affect the impact of local anaesthetic were also excluded from the research, reducing selection 333 bias.

The most common method for anaesthetizing mandibular teeth is IANB (32). However,

335 IANB is an unreliable anaesthetic method, especially in the case of IP; even when correctly 336 administered, the success rate varied from 15-25\% (21,26,32). This emphasises the need of having 337 alternatives to IANB (26). Thus, in the present systematic review, the pulpal anaesthetic efficacy 338 between articaine and lidocaine were assessed using various infiltration and block techniques. For 339 mandibular teeth IANB, BI, supplementary BI, and intraligamentary injections after IANB failure, 340 BI combined with intraligamentary injection, standard IANB, and long BIs, IANB plus BI and for

341 maxillary teeth via BI, AMSA and IONB were used. The 2011 meta-analysis by Brandt et al (50)

342 found that articaine as an infiltrating agent was 3.8-fold more likely to be successful than lidocaine.

343 A recent meta-analysis by Kung et al. (16) demonstrated that in cases of a failed IANB, 
344 supplementary infiltration with $4 \%$ articaine was 3.55-fold more successful in achieving profound 345 anaesthetic effect than 2\% lidocaine.

346 Various criteria were applied in this review to assess the first pulpal anaesthetic success,

347 including lip numbness, cold testing, and electric pulp testing. Lip numbness was noted in the 348 majority of the trials, albeit it was a subjective symptom. Only a few studies used a cold test or an 349 electric pulp test followed by lip numbness to validate the first pulpal anaesthetic success, as there 350 was a weak connection between lip anaesthesia, cold testing, and pulpal anaesthesia following 351 IANB for IP mandibular molars $(26,28)$. Bjorn was the first to link a negative response to the 352 maximal output of electrical pulp stimulation for painless dental treatment (51). Dreven et al. 353 examined the reaction to an electric pulp tester as a measure of pulpal anaesthetic prior to 354 endodontic treatment in teeth with normal pulp, reversible pulpitis, and irreversible pulpitis (52). In IP, however, a lack of reaction to cold or electric pulp tests does not always imply pulpal anaesthesia (52). This might be because in teeth with IP, the reactions to electric pulp tests and cold testing are linked to rapid and slow silent A-delta fibres, respectively.

Therefore, it can be assumed that if the tetrodotoxin-resistant sodium channels appear on deeper nociceptive $\mathrm{C}$ fibres, then neither negative nor positive responses to EPT and cold tests indicate the success of anaesthesia as the C fibres might be accountable for the pain response (26, 50). Hence, an appropriate alternative is to record the pain response during access cavity opening and pulp extirpation. All the studies included in the systematic review assessed the clinical success of $4 \%$ articaine and $2 \%$ lidocaine based on pain response during access preparation using VAS. 
367 rate. Furthermore, there was methodological variability in terms of research location, study setting,

368 sample size, number and expertise of investigators performing procedures and diagnosis, volume

369 of LA solution, epinephrine concentration, and marking on the pain scale. This heterogeneity was

370 addressed by using a random-effects model for meta-analysis (16). This meta-analysis found that

371 when used in mandibular and maxillary block and infiltration anaesthesia, $4 \%$ articaine, which is

372 a more concentrated LA solution, was more likely to provide anaesthetic success than less

373 concentrated $2 \%$ lidocaine anaesthetic solution. Besides, wide CIs were observed in the forest plot

374 analysis, potentially contributing to heterogeneity as shown by $\mathrm{I}^{2}$ estimates, i.e. $72 \%$, with

375 statistically significant difference favouring the articaine group for mandibular teeth (Figure 3) as

376 compared to narrower CIs contributing to $0 \%$ heterogeneity favouring the articiane group with

377 non-significant difference favouring the articaine group for maxillary teeth (Figure 4). Similar

378 results were reported by previous meta-analysis that were conducted $(13,14,16,50)$. Discrepancies

379 in the chemical properties of the molecular structures of the 4 percent articaine and 2 percent

380 lidocaine LA agents might have resulted in clinical differences. The uncharged form of a LA

381 molecule is required for diffusion across the sheaths of lipid neurons and cell membranes, therefore

382 the anaesthetic dissociation constant (pKa) is a crucial number for successful anaesthesia (14). In

383 addition to ionisation, fat solubility and protein-binding properties contribute to the clinical

384 characteristics of LAs whereas, their clinical performance is influenced by the site of injection,

385 concentration of drug and vasoconstrictor, injection volume, and anaesthetic solution's inherent

386 vasodilatory properties $(14,53,54)$. A previous study showed that articaine suppresses the

387 compound action potential of the A fibres in the isolated rat sural nerve (55). Also, ionic channels

388 are blocked even in lower concentrations with the thiophene derivative (articaine) as compared to

389 the benzene derivative (lidocaine) (56). 
391 were one of the major challenges posed by this meta-analysis. In the sub-group analysis, a

392 significant advantage of using articaine over lidocaine for supplementary infiltration after

393 mandibular block anaesthesia over the mandibular block and infiltration anaesthesia alone was

394 observed with heterogeneity of 36\% (Fig. 3). Another meta-analysis by Brandt et al. (50) showed

395 that the pulpal anaesthetic efficacy of articaine was markedly superior to lidocaine when used

396 during infiltration. One study each for supplementary intraligamentary injection, IANB plus long

397 buccal, and IANB with BI was included in the subgroup analysis for mandibular teeth. However,

398 to evaluate whether the final results were dependent on subgroup results of these single studies, a

399 sensitivity analysis was performed via meta-analysis by excluding the above studies in question.

400 This analysis confirmed that although the exclusion of the studies reduced the RRs and

401 heterogeneity, the overall results were unchanged (Table 4).

402 The secondary objective of this systematic review was to assess the postoperative pain and 403 mean onset time of the two LA solutions. The group receiving $4 \%$ articaine, as opposed to $2 \%$

404 lidocaine, experienced less pain as measured by VAS during the injection and treatment phases,

405 which might be due to articaine's 1.5-fold higher potency than lidocaine's (13). In terms of onset

406 time, 4 percent articaine was shown to be faster than 2 percent lidocaine in pulpal anaesthesia.

407 This phenomenon might be explained by the fact that the onset period of anaesthesia is

408 proportional to the pace of epineural diffusion. This rate is proportional to the percentage of drug

409 in the base form, which is proportional to the pKa; articaine's pKa was lower than lidocaine's (13). 410

411 Intriguingly, when this study was compared to prior English language systematic reviews

$412(13,16,50,57)$, there were some striking similarities and variations in terms of anaesthetic solution 
413 and administration techniques. Except for the reviews by Su et al. (13) and Kung et al. (50), the

414 main difference between this and previous reviews $(13,16,50,57)$ is that all subjects in this review

415 were diagnosed with IP, whereas previous reviews consisted of a broad cohort of patients and non-

416 patient volunteers with or without pain $(15,16)$. In comparison to the current analysis, which

417 comprised parallel-design clinical trials, earlier reviews by Brandt et al (50) and Katyal (57) used

418 crossover design. In comparison to prior research, the start and end of the search time changed in

419 the current study. Previous studies mostly looked at adverse events, pain, and the onset of local

420 anaesthetic, but this study examined at the total clinical success rate as well as subgroup and

421 sensitivity analyses.

422 Nevertheless, the present review has some limitations. It was not possible to fully avoid

423 the clinical heterogeneity among the included studies. The sample size of the studies was small,

424 thus lacking statistical power. The reasons for the difference in postoperative pain and the onset

425 time could not be explained because of lack of evidence. Individual tooth type analysis (incisors,

426 canines, premolars, and molars) was not performed, and age and gender were also not taken into

427 consideration in the analysis. However, 15 studies rated good on methodological validity

428 assessment, exhibiting a low risk of bias. The subgroup and sensitivity analyses were performed

429 to rule out the potential reasons for heterogeneity. Thus, it is suggested that in the future, high-

430 quality clinical trials on the outcomes of onset of anaesthesia and pain assessment at various stages

431 of the treatment procedure of IP should be conducted along with the trials assessing the adverse

432 effects of the two solutions at varying concentrations and sites of injection.

433

434

435 Conclusions

Peer] reviewing PDF | (2021:04:60501:1:1:NEW 17 Aug 2021) 
437 mandibular block or maxillary infiltration in patients with symptomatic IP, articaine is superior to 438 lidocaine. For mandibular teeth, 4 percent articaine had a clinical success rate 1.37 times greater 439 than 2 percent lidocaine, and 1.06 times higher for maxillary teeth.

440

\section{KEY HIGHLIGHTS of the current analysis:}

442 1. Successful pulpal anaesthesia is the cornerstone for painless root canal treatment, especially in 443 patients with symptomatic pulpitis.

444 2. Articaine was introduced to overcome supplemental anaesthesia and to increase the 445 effectiveness of the quality of anaesthesia.

446 3. Articaine is associated with a lower visual analogue scale rating for pain.

447 4. Articaine resulted in 1.37-fold and 1.06-fold higher clinical success rate than lidocaine for 448 mandibular and maxillary teeth respectively.

\section{References:}

451

452

1. World Health Organization. Sugars and dental caries. World Health Organization; 2017. Available at: https://apps.who.int/iris/bitstream/handle/10665/259413/WHO-NMH-NHD17.12-eng.pdf. Accessed date: 23/10/2020

2. Rôças IN, Lima KC, Assunção IV, Gomes PN, Bracks IV, Siqueira Jr JF. Advanced caries microbiota in teeth with irreversible pulpitis. J Endod 2015;41(9):1450-5.

3. Li C, Yang X, Ma X, Li L, Shi Z. Preoperative oral nonsteroidal anti-inflammatory drugs for the success of the inferior alveolar nerve block in irreversible pulpitis treatment: a systematic 
458 review and meta-analysis based on randomised controlled trials. Quintessence Int $459 \quad 2012 ; 43: 209-19$.

460 4. Zanjir M, Lighvan NL, Yarascavitch C, Beyene J, Shah PS, Azarpazhooh A. Efficacy and 461 safety of pulpal anaesthesia strategies during endodontic treatment of permanent mandibular 462 molars with symptomatic irreversible pulpitis: a systematic review and network meta-analysis. $463 \quad J$ Endod 2019;45(12):1435-64.

464 5. Subbiya A, Pradeepkumar AR. Pain management in endodontics. J Oper Dent Endod $465 \quad 2016 ; 1(2): 76-81$.

466 6. Howait M, Basunbul GI. Prevalence of failed inferior alveolar nerve block (IANB) in 467 achieving pulpal anaesthesia in mandibular molars with symptomatic irreversible pulpitis. 468 E.D.J 2019;65:771-6.

469 7. Reader A, Nusstein JM, Hargreaves KM. Local anesthesia in endodontics. In: Hargreaves KM, 470 Cohen S, eds. Cohen's Pathways of the Pulp. St. Louis, MO: Mosby; 2011:691-719.

471 8. Modaresi J, Davoudi A, Badrian H, Sabzian R. Irreversible pulpitis and achieving profound 472 anesthesia: complexities and managements. Anesth Essays Res 2016;10(1):3.

473 9. Shahi S, Rahimi S, Yavari HR, Ghasemi N. and Ahmadi F.. Success rate of 3 injection methods 474 with articaine for mandibular first molars with symptomatic irreversible pulpitis: a CONSORT 475 randomised double-blind clinical trial. J Endod 2018;44(10):1462-1466.

10. Sherman MG, Flax M, Namerow K, Murray PE. Anesthetic efficacy of the Gow-Gates 477 injection and maxillary infiltration with articaine and lidocaine for irreversible pulpitis. $J$ $478 \quad$ Endod 2008;34(6):656-659.

479 11. Dou L, Luo J, Yang D, Wang Y. The effectiveness of an additional lingual infiltration in the 480 pulpal anesthesia of mandibular teeth: a systematic review. Quintessence Int 2013;44:457-64. 
481 12. Dou L, Vanschaayk MM, Zhang Y, Fu X, Ji P, Yang D. The prevalence of dental anxiety and 482 its association with pain and other variables among adult patients with irreversible pulpitis. $483 \quad$ BMC oral health. 2018;18(1):101.

484 13. Su N, Li C, Wang H, Shen J, Liu W, Kou L. Efficacy and safety of articaine versus lidocaine 485 for irreversible pulpitis treatment: a systematic review and meta-analysis of randomised 486 controlled trials. Aust Endod J. 2016;42(1):4-15.

487 14. de Geus JL, da Costa JK, Wambier LM, Maran BM, Loguercio AD, Reis A. Different 488 anesthetics on the efficacy of inferior alveolar nerve block in patients with irreversible pulpitis: 489 A network systematic review and meta-analysis. JADA 2020;151(2):87-97.

490 15. Srinivasan MR, Poorni S, Nitharshika Y, Diana D, Duraivel D. Articaine buccal infiltration 491 versus lignocaine inferior alveolar block for pulpal anaesthesia in mandibular second 492 premolars-Randomised control double blinded clinical trial. Journal of Pierre Fauchard 493 Academy (India Section) 2017;31(2-4):79-83.

494 16. Kung J, McDonagh M, Sedgley CM. Does articaine provide an advantage over lidocaine in 495 patients with symptomatic irreversible pulpitis? A systematic review and meta-analysis. $J$ $496 \quad$ Endod 2015;41(11):1784-94.

497 17. The Joanna Briggs Institute Levels of Evidence and Grades of Recommendation Working 498 Party*. Supporting Document for the Joanna Briggs Institute Levels of Evidence and Grades 499 of Recommendation. The Joanna Briggs Institute. 2014. URL accessed at: 500 https://joannabriggs.org/sites/default/files/2019-05/JBI-Levels-of-evidence 2014 0.pdf.

$501 \quad$ Accessed date: $23 / 10 / 2020$

502 18. Higgins JP, Thomas J, Chandler J, Cumpston M, Li T, Page MJ, Welch VA, editors. Cochrane 503 handbook for systematic reviews of interventions. John Wiley \& Sons; 2019. 
504 19. Slim K, Nini E, Forestier D, Kwiatkowski F, Panis Y, Chipponi J. Methodological index for 505 non-randomised studies (MINORS): development and validation of a new instrument. ANZ J

$506 \quad$ Surg 2003;73(9):712-6.

507 20. Gao X, Meng K. Comparison of articaine, lidocaine and mepivacaine for buccal infiltration 508 after inferior alveolar nerve block in mandibular posterior teeth with irreversible pulpitis. $\mathrm{Br}$ 509 Dent J. 2020;228(8):605-8.

510 21. Kumar BP, Sirisha K, Jyothi M, Rao SA. Comparative evaluation of anesthetic efficacy of 2\% 511 lidocaine and 4\% articaine in irreversible pulpitis cases during endodontic therapy - a 512 randomised double blind study. Ind J Conserv Endod 2020;5(1):6-10.

513 22. Aggarwal V, Singla M, Miglani S, Kohli S. Efficacy of articaine versus lidocaine administered 514 as supplementary intraligamentary injection after a failed inferior alveolar nerve block: a 515 randomised double-blind study. J Endod 2019;45(1):1-5.

516 23. Ghazalgoo A, Saatchi M, Khazaei S, Shadmehr E. The effect of using articaine versus 517 lidocaine for inferior alveolar nerve block on pain after root canal treatment: A prospective, 518 randomised clinical study. Dent Hypotheses 2018;9(4):80.

519 24. Lokhande P, Shivanna V, Manne D, Vidhi S. Efficacy of articaine versus lidocaine, as a buccal 520 infiltration combined with intraligamentary injection, in mandibular molars with irreversible 521 pulpitis--a clinical trial study. J Evolution Med Dent Sci 2019;8(15):1216-9.

522 25. Martínez-Martínez A, Freyle-Granados E, Senior-Carmona N. Efficacy of 2\% lidocaine and 523 4\% articaine in mandibular molars with different pulp diagnoses in the mandibular technique.

524 Rev Fac Odontol Univ Antioq 2018;30(1):5-13.

525 26. Shapiro MR, McDonald NJ, Gardner RJ, Peters MC, Botero TM. Efficacy of articaine versus 526 lidocaine in supplemental infiltration for mandibular first versus second molars with 
527 irreversible pulpitis: a prospective, randomised, double-blind clinical trial. J Endod $528 \quad 2018 ; 44(4): 523-8$.

529 27. Aggarwal V, Singla M, Miglani S. Comparative evaluation of anesthetic efficacy of $2 \%$ 530 lidocaine, $4 \%$ articaine, and $0.5 \%$ bupivacaine on inferior alveolar nerve block in patients with 531 symptomatic irreversible pulpitis: A prospective, randomized, double-blind clinical trial. J $532 \quad$ Orofac pain 2017;31(2).

533 28. Umesh G. Comparative evaluation of anaesthetic efficacy of 2\% lidocaine+ 1: 80,000 534 epinephrine and 4\% articaine+ 1: 1, 00,000 epinephrine buffered with $0.5 \mathrm{Mol} / \mathrm{L}$ mannitol Or $5358.4 \%$ sodium bicarbonate on the success of inferior alveolar nerve block for teeth with 536 symptomatic irreversible pulpitis: An invivo study (Doctoral dissertation, Tamil Nadu 537 Government Dental College and Hospital, Chennai).

538 29. Allegretti CE, Sampaio RM, Horliana AC, Armonia PL, Rocha RG, Tortamano IP. Anesthetic 539 efficacy in irreversible pulpitis: a randomised clinical trial. Braz.Dent.J 2016;27(4):381-6.

540 30. Hosseini HR, Parirokh M, Nakhaee N, Abbott PV, Samani S. Efficacy of articaine and 541 lidocaine for buccal infiltration of first maxillary molars with symptomatic irreversible 542 pulpitis: a randomised double-blinded clinical trial. IEJ 2016;11(2):79.

543 31. Saraf SP, Saraf PA, Kamatagi L, Hugar S, Tamgond S, Patil J. A comparative evaluation of 544 anesthetic efficacy of articaine $4 \%$ and lidocaine $2 \%$ with anterior middle superior alveolar nerve block and infraorbital nerve block: An in vivo study. J Conserv Dent 2016;19(6):527.

546 32. Zain M, Rehman SK, Sikandar H, Shah SA. Comparison of anaesthetic efficacy of 4\%

547 articaine primary buccal infiltration versus 2\% lidocaine inferior alveolar nerve block in 548 symptomatic mandibular first molar teeth. JCPSP 2016;26(1):4-8. 
549 33. Monteiro MR, Groppo FC, Haiter-Neto F, Volpato MC, Almeida JF. 4\% articaine buccal

550 infiltration versus $2 \%$ lidocaine inferior alveolar nerve block for emergency root canal

551 treatment in mandibular molars with irreversible pulpits: a randomised clinical study. Int

$552 \quad$ Endod J. 2015;48(2):145-52.

553 34. Rajput F, Katpar S, Shaikh MI, Khatoon S. Evaluation of anesthetic efficacy of 4\% articaine as buccal infiltration vs $2 \%$ lidocaine as ianb in the mandibular 1 st molar with irreversible pulpitis. Pak Oral Dent J 2015;35(1).

35. Ahmad ZH, Ravikumar H, Karale R, Preethanath RS, Sukumaran A. Study of the anesthetic efficacy of inferior alveolar nerve block using articaine in irreversible pulpitis. J Contemp Dent Pract 2014;15(1):71-4.

36. Nabeel M, Ahmed A, Sikander M. A comparison of the anesthetic efficacy of lidocaine and articaine for buccal infiltration in patients with acute irreversible pulpitis in maxillary first premolars. Pak Oral Dent J 2014;34(4).

37. Rogers BS, Botero TM, McDonald NJ, Gardner RJ, Peters MC. Efficacy of articaine versus lidocaine as a supplemental buccal infiltration in mandibular molars with irreversible pulpitis: epinephrine and 2\% lidocaine with 1: 80,000 epinephrine for inferior alveolar nerve block in patients with irreversible pulpitis. J Clin Exp Dent 2014;6(5):e520.

39. Ashraf H, Kazem M, Dianat O, Noghrehkar F. Efficacy of articaine versus lidocaine in block and infiltration anesthesia administered in teeth with irreversible pulpitis: a prospective, randomised, double-blind study. J Endod 2013;39(1):6-10. 
571 40. Tortamano IP, Siviero M, Lee S, Sampaio RM, Simone JL, Rocha RG. Onset and duration 572 period of pulpal anesthesia of articaine and lidocaine in inferior alveolar nerve block. 573 Braz.Dent.J 2013;24(4):371-4.

574 41. Kanaa MD, Whitworth JM, Meechan JG. A comparison of the efficacy of 4\% articaine with 575 1: 100,000 epinephrine and 2\% lidocaine with 1: 80,000 epinephrine in achieving pulpal 576 anesthesia in maxillary teeth with irreversible pulpitis. J Endod 2012;38(3):279-82.

577 42. Kanaa MD, Whitworth JM, Meechan JG. A prospective randomised trial of different 578 supplementary local anesthetic techniques after failure of inferior alveolar nerve block in 579 patients with irreversible pulpitis in mandibular teeth. J Endod 2012;38(4):421-5.

580 43. Subbiya A, Pradeepkumar AR, Vivekanandhan P, Karthick A. Comparative efficacy 581 evaluation of articaine as buccal infiltration and lignocaine as IANB in the mandibular first 582 molar with irreversible pulpitis. Indian J Multidiscip Dent 2011;2(1).

583 44. Aggarwal V, Singla M, Rizvi A, Miglani S. Comparative evaluation of local infiltration of 584 articaine, articaine plus ketorolac, and dexamethasone on anesthetic efficacy of inferior 585 alveolar nerve block with lidocaine in patients with irreversible pulpitis. J Endod $2011 ; 37(4): 445-9$

45. Poorni S, Veniashok B, Senthilkumar AD, Indira R, Ramachandran S. Anesthetic efficacy of 588 four percent articaine for pulpal anesthesia by using inferior alveolar nerve block and buccal infiltration techniques in patients with irreversible pulpitis: a prospective randomised doubleblind clinical trial. J Endod 2011;37(12):1603-7.

591

46. Aggarwal V, Jain A, Debipada K. Anesthetic efficacy of supplemental buccal and lingual 592 infiltrations of articaine and lidocaine following an inferior alveolar nerve block in patients with irreversible pulpitis. J Endod 2009;35:925-9. 
594 47. Hargreaves KM, Keiser K. Local anesthetic failure in endodontics: mechanisms and 595 management. Endod Topics 2002;1:26-39.

596 48. Goranka Prpic-Mehicic, Nada Galic. Odontogenic pain. Medical Sciences 2010; 34:43-54.

597 49. Oxford Centre for Evidence-Based Medicine. Levels of evidence. BJU Int 2009;104(11).

598 50. Brandt RG, Anderson PF, McDonald NJ, Sohn W, Peters MC. The pulpal anesthetic efficacy 599 of articaine versus lidocaine in dentistry: a meta-analysis. JADA 2011;142(5):493-504.

600 51. Bjorn H. Electrical excitation of teeth and its application to dentistry. Swed Dent J 1946;39:8760196.

602 52. Dreven LJ, Reader A, Beck M, Meyers WJ, Weaver J. An evaluation of an electric pulp tester 603 as a measure of analgesia in human vital teeth. J Endod 1987;13:233-8.

604 53. Haas DA. An update on local anesthetics in dentistry. J Can Dent Assoc 2002;68(9):546-551.

605 54. Moore PA, Hersh EV. Local anesthetics: pharmacology and toxicity. Dent Clin N Am $606 \quad 2010 ; 54: 587-599$.

607 55. Potonik I, Tomi M, Sketelj J, Bajrovi FF. Articaine is more effective than lidocaine or 608 mepivacaine in rat sensory nerve conduction block in vitro. J Dent Res 2006;85:162-6.

609 56. Kolli NK, Nirmala SV, Nuvvula S. The effectiveness of articaine and lidocaine single buccal 610 infiltration versus conventional buccal and palatal injection using lidocaine during primary 611 maxillary molar extraction: A randomised control trial. Anesth essays Res 2017;11(1):160.

612 57. Katyal V. The efficacy and safety of articaine versus lignocaine in dental treatments: A meta613 analysis. J Dent 2010;38(4):307-17. 


\section{FIGURE LEGENDS:}

617 Figure 1- PRISMA flow diagram

618 Figure 2- Risk of bias summary: a) Review authors' judgements about each risk of bias item for

619 each included study, b) Review authors' judgements about each risk of bias item presented as 620 percentages across all included studies.

621 Figure 3 -Forest plot of the pooled analysis and the subgroup analysis comparing $4 \%$ articaine 622 with $2 \%$ lidocaine in the clinical success of mandibular block and infiltration anaesthesia for 623 irreversible pulpitis in tooth unit

624 Figure 4 -Forest plot comparing 4\% with $2 \%$ lidocaine in the clinical success rate of maxillary 625 buccal infiltration for irreversible pulpitis in tooth unit

626 Figure 5 -Funnel plot comparing $4 \%$ articaine with $2 \%$ lidocaine in the clinical success of 627 mandibular block and infiltration anaesthesia for irreversible pulpitis in tooth unit

628 Figure 6. The chemical structure of Lidocaine and Articaine.

629

630 
Figure 1

PRISMA flow diagram

PRISMA flow diagram 


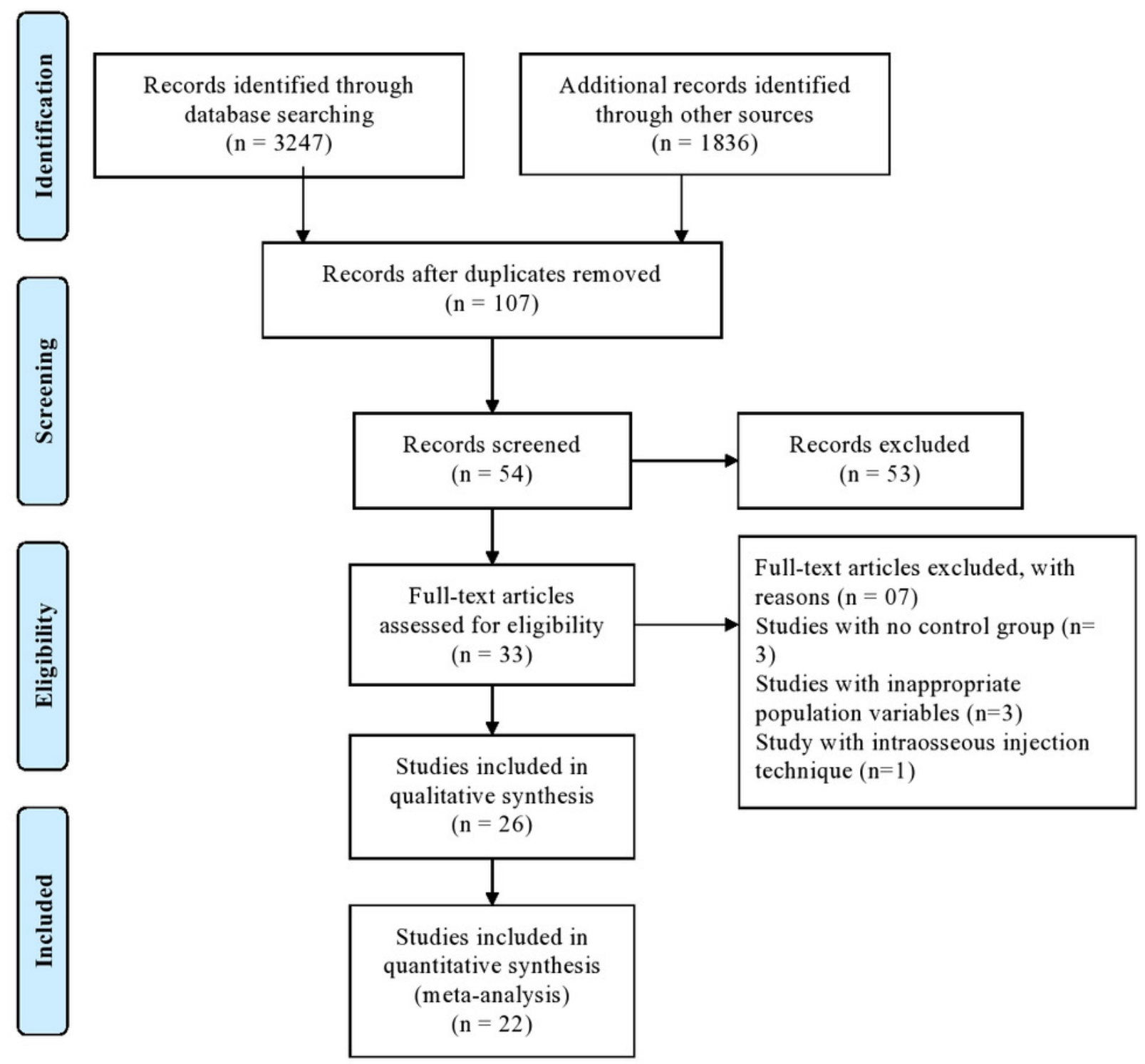


Figure 2

Risk of bias summary: a) Review authors' judgements about each risk of bias item for each included study, b) Review authors' judgements about each risk of bias item presented as percentages across all included studies.

Risk of bias summary: a) Review authors' judgements about each risk of bias item for each included study, b) Review authors' judgements about each risk of bias item presented as percentages across all included studies.
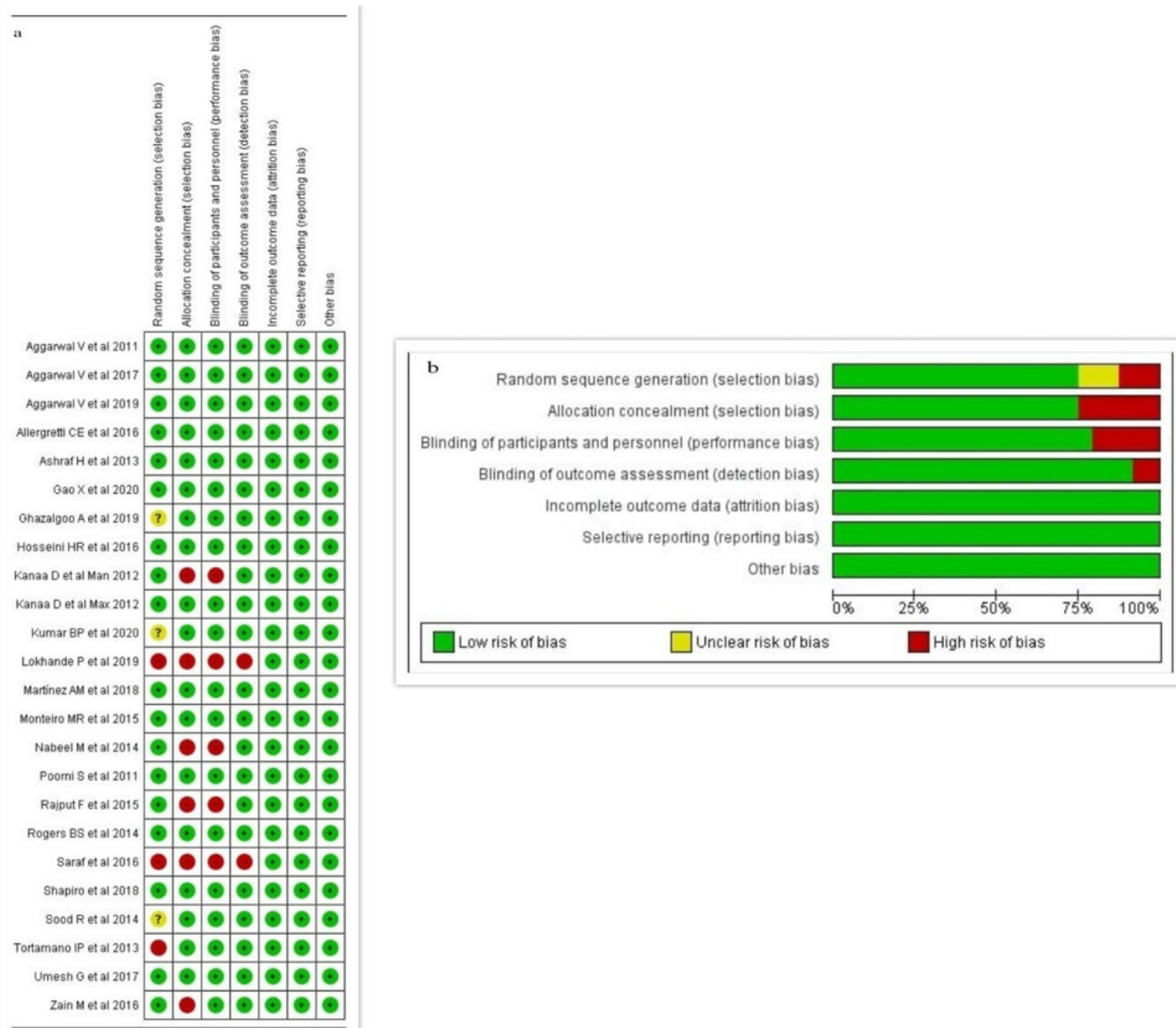


\section{Figure 3}

Forest plot of the pooled analysis and the subgroup analysis comparing $4 \%$ articaine with $2 \%$ lidocaine in the clinical success of mandibular block and infiltration anaesthesia for irreversible pulpitis in tooth unit.

Forest plot of the pooled analysis and the subgroup analysis comparing $4 \%$ articaine with $2 \%$ lidocaine in the clinical success of mandibular block and infiltration anaesthesia for irreversible pulpitis in tooth unit. 
4\% Articaine 2\% Lidocaine Risk Ratio

Study or Subgroup

Events Total Events Total Weight $\mathrm{M}-\mathrm{H}, \mathrm{Random}, \mathbf{9 5} \% \mathrm{Cl}$ 1.1.1 Inferior alveolar nerve block

Agganwal $V$ et al 2017

Ahmad $\mathrm{ZH}$ et al 2014

$10 \quad 30$

Allergretti CE et al 2016

Kumar BP et al 2020

Martínez AM et al 2018

Poorni S et al 2011

Sood R et al 2014

Subtotal $(95 \% \mathrm{Cl})$

Total events

$13 \quad 15$

$14 \quad 22$

713

418

$36 \quad 52$

$44 \quad 50$

200

128

Heterogeneity: Tau $^{2}=0.04 ; \mathrm{Ch}^{2}=10.49, \mathrm{df}=6(\mathrm{P}=0.11) ; \mathrm{I}^{2}=43 \%$

Test for overall effect: $Z=1.82(P=0.07)$

\subsubsection{Buccal infiltration}

Kumar BP et al 2020

Monteiro MR et al 2015

Poorni $S$ et al 2011

Rajput F et al 2015

Subbiya A et al 2012

Zain M et al 2016

Subtotal $(95 \% \mathrm{Cl})$

Total events

$\begin{array}{rr}5 & 6 \\ 12 & 30 \\ 34 & 52 \\ 22 & 30 \\ 22 & 30 \\ 60 & 70 \\ & \mathbf{2 1 8}\end{array}$

$\begin{array}{lll}7 & 31 & 2.7 \%\end{array}$

$6 \quad 15 \quad 3.6 \%$

$12 \quad 22 \quad 4.8 \%$

$2 \quad 12 \quad 1.2 \%$

$1 \quad 18 \quad 0.6 \%$

$\begin{array}{rrr}1 & 18 & 0.6 \% \\ 34 & 52 & 6.8 \%\end{array}$

$41 \quad 50 \quad 7.7 \%$ 103

$200 \quad 27.4 \%$

Heterogeneity: Tau $^{2}=0.06 ; \mathrm{Chi}^{2}=15.48, \mathrm{df}=5(\mathrm{P}=0.009) ; \mathrm{I}^{2}=68 \%$

Test for overall effect: $Z=1.01(P=0.31)$

1.1.3 Supplementary buccal infiltration after IANB failure

$\begin{array}{lllrrr}\text { Gao X et al 2020 } & 43 & 52 & 30 & 52 & 6.9 \% \\ \text { Kanaa D et al 2012 a } & 21 & 25 & 8 & 25 & 4.0 \% \\ \text { Rogers BS et al 2014 } & 24 & 39 & 13 & 35 & 4.7 \% \\ \text { Shapiro et al 2018 } & 47 & 76 & 35 & 73 & 6.6 \%\end{array}$

Subtotal (95\% CI)

Total events

135

86

Heterogeneity: Tau $^{2}=0.02 ; \mathrm{Chi}^{2}=4.70, \mathrm{df}=3(\mathrm{P}=0.20) ; \mathrm{I}^{2}=36 \%$

Test for overall effect: $Z=3.56(P=0.0004)$

1.1.4 Buccal infiltration combined with intraligamentary injection

Lokhande $\mathrm{P}$ et al $2019-25-30-30-1.8 \%$

Subtotal $(95 \% \mathrm{Cl})$

$25 \quad 30$

$\begin{array}{lll}3 & 30 & 1.8 \% \\ 30 & 1.8 \%\end{array}$

Total events 25

3

Heterogeneity: Not applicable

Test for overall effect: $Z=3.83(P=0.0001)$

1.1.5 Supplementary intraligamentary injections after IANB failure

$\begin{array}{lccccc}\text { Agganwal V et al 2019 } & 27 & 41 & 30 & 41 & 6.6 \% \\ \text { Subtotal (95\% Cl) } & & \mathbf{4 1} & & \mathbf{4 1} & \mathbf{6 . 6 \%} \\ \text { Total events } & 27 & & 30 & & \end{array}$

Total events
Heterogeneity: Not applicable

Test for overall effect: $Z=0.72(P=0.47)$

1.1.6 Standard IANB and long buccal injections

Ashraf H et al 2013

Subtotal $(95 \% \mathrm{CI})$

$41 \quad 58$

Total events

41

$\begin{array}{llll}\mathbf{5 8} & 17 & 58 & 5.3 \% \\ \mathbf{5 8} & & \mathbf{5 8} & \mathbf{5 . 3} \%\end{array}$

Heterogeneity: Not applicable

Test for overall effect: $Z=3.99$ ( $P<0.0001$ )

1.1.7 IANB plus buccal infiltration

$\begin{array}{lllllll}\text { Aggarwal V et al 2011 } & 13 & 24 & 9 & 23 & 3.8 \% & 1.38[0.74,2.60] \\ \begin{array}{l}\text { Subtotal (95\% Cl) } \\ \text { Total events }\end{array} & 13 & \mathbf{2 4} & & \mathbf{2 3} & \mathbf{3 . 8} \% & \mathbf{1 . 3 8}[\mathbf{0 . 7 4}, \mathbf{2 . 6 0}] \\ & 13 & 9 & & & \end{array}$

Heterogeneity: Not applicable

Test for overall effect: $Z=1.01(P=0.31)$

Total $(95 \% \mathrm{Cl})$

763

Total events

$524 \quad 386$

$767100.0 \%$

Heterogeneity: Tau $^{2}=0.08 ; \mathrm{Chi}^{2}=72.35, \mathrm{df}=20(\mathrm{P}<0.00001) ; \mathrm{I}^{2}=72 \%$

Test for overall effect: $Z=3.78(P=0.0002)$

Test for subqroup differences: $\mathrm{Chi}^{2}=28.52, \mathrm{df}=6(\mathrm{P}<0.0001), \mathrm{I}^{2}=79.0 \%$
$8.33[2.81,24.67]$

$1.43[1.10,1.87]$

$2.63[1.45,4.77]$

$1.66[1.01,2.72]$

$1.29[0.96,1.74]$

$1.53[1.21,1.94]$

$1.48[0.65,3.37]$

$17[1.13,4.15]$

$3.23[0.83,12.61]$

$4.00[0.49,32.39]$

$1.06[0.81,1.38]$

$1.25[0.98,1.59]$

$1.19[0.69,2.04]$

$00[1.47,24.55]$

1010.79 .1

$0.85[0.65,1.09]$

$1.13[0.89,1.45]$

$8.33[2.81,24.67]$

$0.90[0.67,1.20]$

$0.90[0.67,1.20]$

$2.41[1.56,3.72]$

$2.41[1.56,3.72]$
$1.36[1.12,1.66]$
Risk Ratio

M-H, Random, $95 \% \mathrm{Cl}$

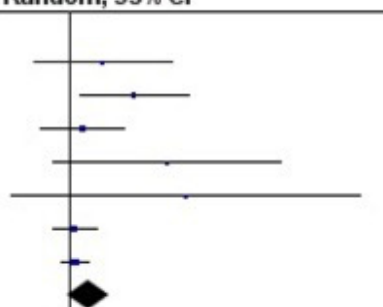




\section{Figure 4}

Forest plot comparing $4 \%$ with $2 \%$ lidocaine in the clinical success rate of maxillary buccal infiltration for irreversible pulpitis in tooth unit.

Forest plot comparing $4 \%$ with $2 \%$ lidocaine in the clinical success rate of maxillary buccal infiltration for irreversible pulpitis in tooth unit.

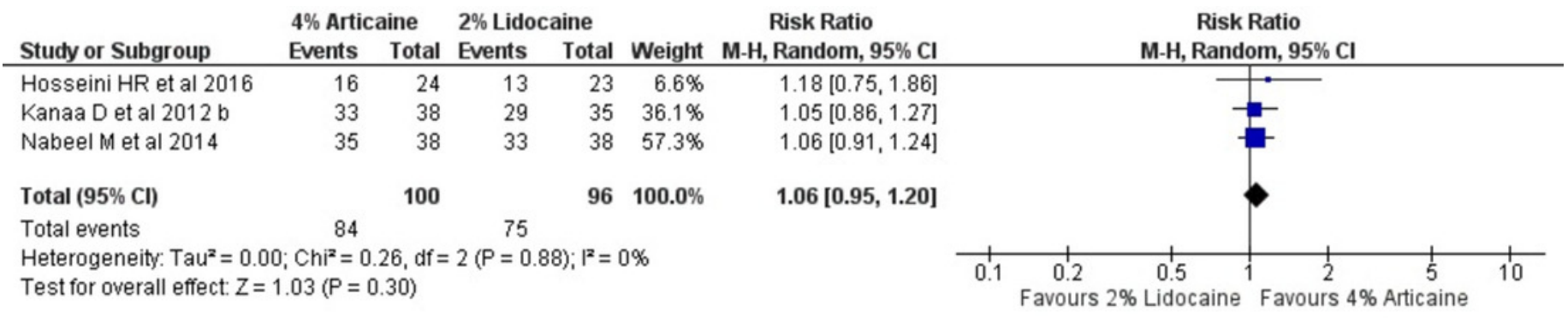




\section{Figure 5}

Funnel plot comparing $4 \%$ articaine with $2 \%$ lidocaine in the clinical success of mandibular block and infiltration anaesthesia for irreversible pulpitis in tooth unit

Funnel plot comparing $4 \%$ articaine with $2 \%$ lidocaine in the clinical success of mandibular block and infiltration anaesthesia for irreversible pulpitis in tooth unit

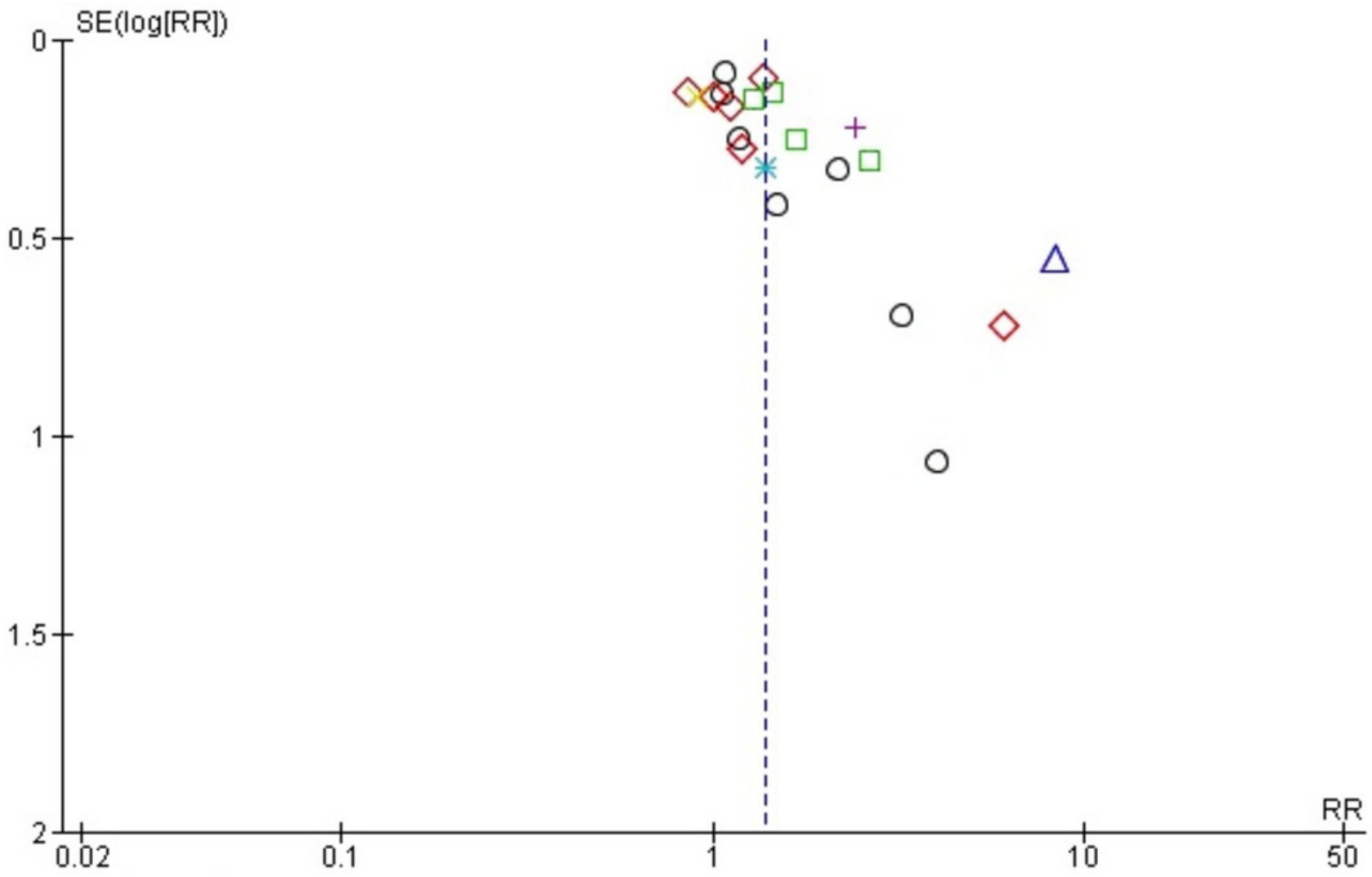

Subgroups

Inferior alveolar nerve block

$\checkmark$ Buccal infiltration

Supplementary buccal infiltration after IANB failure

$\triangle$ Buccal infiltration combined with intraligamentary injection

Supplementary intraligamentary injections after IANB failure

+ Standard IANB and long buccal injections

* IANB plus buccal infiltration 
Figure 6

The chemical structure of Lidocaine and Articaine.

\section{Lidocaine}

Articaine
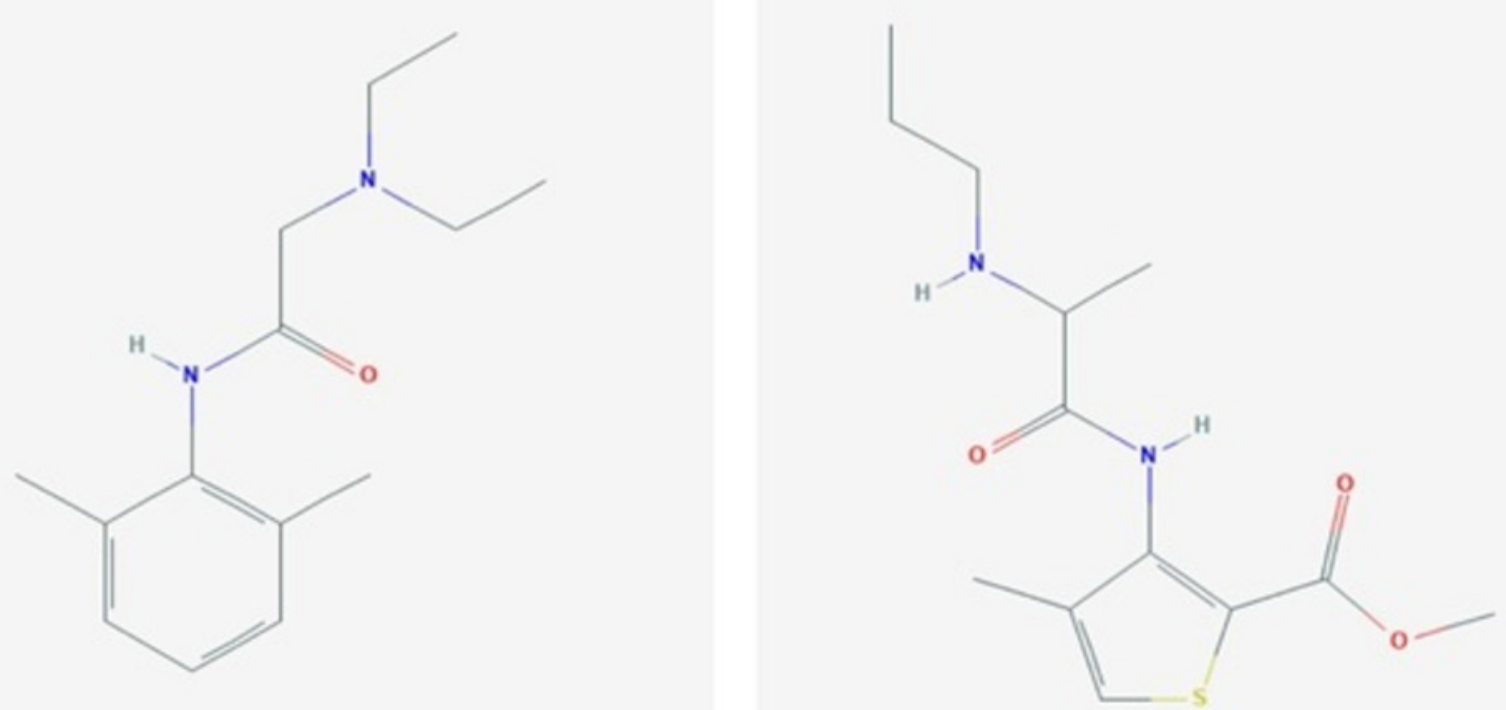
Table $\mathbf{1}$ (on next page)

The search strategy and PICOS tool

The search strategy and PICOS tool 
1 Table 1: The search strategy and PICOS tool

\begin{tabular}{|c|c|}
\hline Search strategy & \\
\hline $\begin{array}{l}\text { Focused } \\
\text { Question } \\
\end{array}$ & $\begin{array}{l}\text { Is there a difference in the efficacy of } 4 \% \text { Articaine versus } 2 \% \text { Lidocaine } \\
\text { in mandibular and maxillary block and infiltration anaesthesia in patients } \\
\text { with irreversible pulpitis? }\end{array}$ \\
\hline Search strategy & \\
\hline Population (\#1) & $\begin{array}{l}\text { ((Irreversible pulpitis [Text Word]) OR ("maxilla"[MeSH Terms] OR } \\
\text { maxillary[Text Word]) AND ("tooth"[MeSH Terms] OR teeth[Text } \\
\text { Word]) OR ("mandible"[MeSH Terms] OR mandibular[Text Word]) } \\
\text { AND ("tooth"[MeSH Terms] OR teeth[Text Word]) OR lower teeth } \\
\text { [Text Word] OR upper teeth [Text Word] OR "molar"[MeSH Terms] } \\
\text { OR molar[Text Word] OR posterior teeth [Text Word] OR anterior } \\
\text { teeth [Text Word] OR premolar [Text Word] OR "incisor"[MeSH } \\
\text { Terms] OR incisor[Text Word] OR canine [MeSH])) }\end{array}$ \\
\hline Intervention (\#2) & $\begin{array}{l}\text { ((Articain [Text Word] OR Articaine [Text Word] OR Carticaine } \\
\text { [MeSH] OR Carticaine Hydrochloride [Text Word] AND (Local } \\
\text { Anesthesia [Text Word] OR Infiltration Anesthesia [Text Word] OR } \\
\text { nerve block [Text Word] OR inferior alveolar nerve block [Text Word] } \\
\text { OR buccal infiltration [Text Word] OR Infra-orbital nerve block [Text } \\
\text { Word] OR Anterior superior nerve block [Text Word] OR Middle } \\
\text { superior nerve block [Text Word])) }\end{array}$ \\
\hline $\begin{array}{l}\text { Comparisons } \\
(\# 3)\end{array}$ & $\begin{array}{l}\text { ((Lidocaine [MeSH] OR Lidocaine Hydrochloride [Text Word] OR } \\
\text { Lignocaine [Text Word]) AND (Local Anesthesia [Text Word] OR }\end{array}$ \\
\hline
\end{tabular}




\begin{tabular}{|c|c|}
\hline & $\begin{array}{l}\text { Infiltration Anesthesia [Text Word] OR nerve block [Text Word] OR } \\
\text { inferior alveolar nerve block [Text Word] OR buccal infiltration [Text } \\
\text { Word] OR Infra-orbital nerve block [Text Word] OR Anterior superior } \\
\text { nerve block [Text Word] OR Middle superior nerve block [Text Word])) }\end{array}$ \\
\hline Outcomes (\#4) & $\begin{array}{l}\text { (Success [Text Word] Pain [Text Word] OR onset time [Text Word] OR } \\
\text { duration [Text Word] OR Visual analogue scale [MeSH] OR Heft Parker } \\
\text { Visual Analog Scale [Text Word]) }\end{array}$ \\
\hline $\begin{array}{l}\text { Study design } \\
(\# 5)\end{array}$ & $\begin{array}{l}\text { (Clinical trials [MeSH] OR randomized controlled studies [Text Word] } \\
\text { OR randomized control trials [MeSH] OR randomized control clinical } \\
\text { trial MeSH OR non-randomized control trials [Text Word] OR Quasi } \\
\text { experimental studies [Text Word] OR before and after study design [Text } \\
\text { Word] OR cohort studies [Text Word] OR in vivo study [Text Word]) }\end{array}$ \\
\hline $\begin{array}{l}\text { Search } \\
\text { Combination }\end{array}$ & $\# 1$ AND \#2 AND \#3 AND \#4 AND \#5 \\
\hline $\begin{array}{l}\text { Database } \\
\text { search }\end{array}$ & \\
\hline Language & $\begin{array}{l}\text { No restriction (Articles in English language or other language where } \\
\text { English translation is possible.) }\end{array}$ \\
\hline $\begin{array}{l}\text { Electronic } \\
\text { Databases }\end{array}$ & $\begin{array}{l}\text { PubMed/MEDLINE, Cochrane Central Register of Controlled Trials, } \\
\text { Web of Science }\end{array}$ \\
\hline Journals & $\begin{array}{l}\text { Journal of Endodontics, International Endodontic Journal, Australian } \\
\text { Endodontic Journal, Clinical Oral Investigations, Journal of Conservative } \\
\text { Dentistry, Journal of American Dental Association }\end{array}$ \\
\hline
\end{tabular}




\begin{tabular}{|l|l|}
\hline $\begin{array}{l}\text { Period of } \\
\text { Publication }\end{array}$ & Studies published between 1-1-2011 to 30-09-2020 \\
\hline
\end{tabular}

2 
Table 2 (on next page)

Characteristics of the included studies

Characteristics of the included studies 
2 Table 2: Characteristics of the included studies

3

\begin{tabular}{|c|c|c|c|c|c|c|c|c|c|c|c|c|c|c|c|c|c|c|}
\hline \multirow[b]{2}{*}{$\begin{array}{l}\text { Stud } \\
\text { y Id }\end{array}$} & \multirow[b]{2}{*}{$\begin{array}{c}\text { Plac } \\
\text { e of } \\
\text { stud } \\
y\end{array}$} & \multirow[b]{2}{*}{$\begin{array}{c}\text { Study } \\
\text { Desig } \\
\text { n }\end{array}$} & \multirow[b]{2}{*}{$\begin{array}{c}\text { Sampl } \\
\text { ing } \\
\text { Techn } \\
\text { ique }\end{array}$} & \multirow[b]{2}{*}{$\begin{array}{l}\text { Sample } \\
\text { Size } \\
\text { Interventi } \\
\text { on/Contr } \\
\text { ol }\end{array}$} & \multirow{2}{*}{$\begin{array}{c}\text { Age } \\
\text { group in } \\
\text { years } \\
\text { Interventi } \\
\text { on/Contr } \\
\text { ol } \\
\text { Mean(SD } \\
\text { ) or } \\
\text { Range }\end{array}$} & \multirow{2}{*}{$\begin{array}{c}\text { Gender } \\
\text { M/F } \\
\text { Interventi } \\
\text { on/Contr } \\
\text { ol } \\
\mathbf{N}\end{array}$} & \multirow[b]{2}{*}{$\begin{array}{l}\text { Teeth } \\
\text { assess } \\
\text { ed }\end{array}$} & \multirow[b]{2}{*}{$\begin{array}{c}\text { Pulp } \\
\text { testi } \\
\text { ng }\end{array}$} & \multirow{2}{*}{$\begin{array}{c}\text { Peria } \\
\text { pical } \\
\text { radiol } \\
\text { ucenc } \\
y / \\
\text { widen } \\
\text { ed } \\
\text { perio } \\
\text { dontal } \\
\text { ligam } \\
\text { ent } \\
\end{array}$} & \multicolumn{2}{|c|}{$\begin{array}{l}\text { Anaesthetic } \\
\text { solution }\end{array}$} & \multicolumn{2}{|c|}{$\begin{array}{c}\text { Anaesthesia } \\
\text { technique }\end{array}$} & \multicolumn{2}{|c|}{$\begin{array}{c}\text { Solution } \\
\text { dosage in }\end{array}$} & \multirow{2}{*}{ 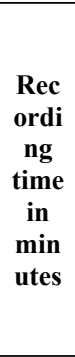 } & \multirow[b]{2}{*}{$\begin{array}{c}\text { Outcom } \\
\text { e } \\
\text { assesse } \\
\text { d }\end{array}$} & \multirow[b]{2}{*}{$\begin{array}{c}\text { Authors } \\
\text { Conclusi } \\
\text { ons }\end{array}$} \\
\hline & & & & & & & & & & $\begin{array}{c}\text { Inter } \\
\text { venti } \\
\text { on } \\
\text { grou } \\
\text { p }\end{array}$ & $\begin{array}{c}\text { Contr } \\
\text { ol } \\
\text { group }\end{array}$ & $\begin{array}{l}\text { Interve } \\
\text { ntion } \\
\text { group }\end{array}$ & $\begin{array}{l}\text { Contro } \\
\text { I group }\end{array}$ & $\begin{array}{c}\text { Inter } \\
\text { venti } \\
\text { on } \\
\text { grou } \\
\text { p }\end{array}$ & $\begin{array}{c}\text { Co } \\
\text { ntr } \\
\text { ol } \\
\text { gro } \\
\text { up }\end{array}$ & & & \\
\hline $\begin{array}{l}\text { Gao } \\
X \text { et } \\
\text { al } \\
(202 \\
0)^{20}\end{array}$ & $\begin{array}{l}\text { Chi } \\
\text { na }\end{array}$ & $\begin{array}{l}\text { Prosp } \\
\text { ective } \\
\text { rando } \\
\text { mised } \\
\text { clinic } \\
\text { al } \\
\text { study }\end{array}$ & $\begin{array}{l}\text { Rando } \\
\mathrm{m} \\
\text { numbe } \\
\text { rs } \\
\text { table }\end{array}$ & $52 / 52$ & $\begin{array}{l}39.2(13.2) \\
/ \\
40.1(12.9)\end{array}$ & $\begin{array}{l}24 \mathrm{M}, 28 \\
\mathrm{~F} / 22 \mathrm{M}, \\
30 \mathrm{~F}\end{array}$ & $\begin{array}{l}\text { Mandi } \\
\text { bular } \\
\text { posteri } \\
\text { or } \\
\text { teeth }\end{array}$ & 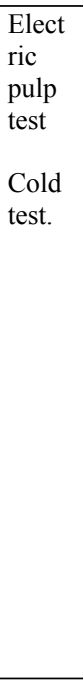 & $\mathrm{No} /-$ & 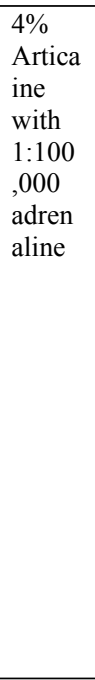 & $\begin{array}{l}2 \% \\
\text { Lidoc } \\
\text { aine } \\
\text { with } \\
1: 100, \\
000 \\
\text { adrena } \\
\text { line }\end{array}$ & $\begin{array}{l}\text { Supple } \\
\text { mentar } \\
\text { y } \\
\text { intralig } \\
\text { amenta } \\
\text { ry BI } \\
\text { after } \\
\text { IANB } \\
\text { failure }\end{array}$ & $\begin{array}{l}\text { Supple } \\
\text { mentar } \\
\text { y } \\
\text { intralig } \\
\text { amenta } \\
\text { ry BI } \\
\text { after } \\
\text { IANB } \\
\text { failure }\end{array}$ & 0.9 & 0.9 & 5 & $\begin{array}{l}\text { Success } \\
\text { of } \\
\text { anaesthe } \\
\text { sia }\end{array}$ & $\begin{array}{l}\text { Suppleme } \\
\text { ntal BI } \\
\text { with } \\
\text { Articaine } \\
\text { following } \\
\text { IANB can } \\
\text { be } \\
\text { considere } \\
\text { d a more } \\
\text { successful } \\
\text { anaestheti } \\
\text { c agent in } \\
\text { mandibul } \\
\text { ar } \\
\text { posterior } \\
\text { teeth with } \\
\text { irreversibl } \\
\text { e pulpitis } \\
\text { compared } \\
\text { with } \\
\text { lidocaine }\end{array}$ \\
\hline
\end{tabular}




\begin{tabular}{|c|c|c|c|c|c|c|c|c|c|c|c|c|c|c|c|c|c|c|}
\hline $\begin{array}{l}\text { Kum } \\
\text { ar } \\
\text { BP } \\
\text { et al } \\
(202 \\
0)^{21}\end{array}$ & $\begin{array}{l}\text { Indi } \\
\mathrm{a}\end{array}$ & $\begin{array}{l}\text { Doubl } \\
\mathrm{e} \\
\text { blind } \\
\text { rando } \\
\text { mized } \\
\text { clinic } \\
\text { al } \\
\text { study }\end{array}$ & $\begin{array}{l}\text { Rando } \\
\text { y } \\
\text { assign } \\
\text { ed }\end{array}$ & $\begin{array}{l}13 / \\
12\end{array}$ & $15-55$ & - & $\begin{array}{l}\text { Sympt } \\
\text { omatic } \\
\text { mandi } \\
\text { bular } \\
\text { posteri } \\
\text { or } \\
\text { teeth }\end{array}$ & $\begin{array}{l}\text { Ther } \\
\text { mal } \\
\text { tests } \\
\text { with } \\
\text { endo } \\
\text { frost } \\
\text { and } \\
\text { heate } \\
\text { d } \\
\text { gutta } \\
\text { - } \\
\text { perch } \\
\text { a } \\
\text { stick } \\
\text { s } \\
\text { Elect } \\
\text { ric } \\
\text { pulp } \\
\text { test }\end{array}$ & $\begin{array}{l}\mathrm{No} / \mathrm{Ye} \\
\mathrm{S}\end{array}$ & $\begin{array}{l}4 \% \\
\text { Artica } \\
\text { ine } \\
\text { with } \\
1: 100 \\
, 000 \\
\text { Epine } \\
\text { phrin } \\
\text { e }\end{array}$ & $\begin{array}{l}2 \% \\
\text { Lidoc } \\
\text { aine; } \\
1: 80,0 \\
00 \\
\text { Epine } \\
\text { phrine }\end{array}$ & IANB & $\begin{array}{l}\text { IANB } \\
\text { BI }\end{array}$ & 1.8 & 1.8 & 15 & $\begin{array}{l}\text { IANB } \\
\text { success } \\
\text { BI } \\
\text { Success }\end{array}$ & $\begin{array}{l}\text { Overall } \\
\text { success } \\
\text { rate with } \\
4 \% \\
\text { Articaine } \\
\text { was } 92 \% \\
\text { and with } \\
2 \% \\
\text { Lidocaine } \\
\text { was } 75 \% \\
\text { after } \\
\text { IANB and } \\
\text { BI. }\end{array}$ \\
\hline $\begin{array}{l}\text { Agg } \\
\text { arwa } \\
1 \mathrm{~V} \\
\text { et al } \\
(201 \\
9)^{22}\end{array}$ & $\begin{array}{l}\text { Indi } \\
\mathrm{a}\end{array}$ & $\begin{array}{l}\text { Rand } \\
\text { omize } \\
\mathrm{d} \text {, } \\
\text { doubl } \\
\text { e- } \\
\text { blind } \\
\text { clinic } \\
\text { al } \\
\text { trial }\end{array}$ & $\begin{array}{l}\text { Online } \\
\text { rando } \\
\mathrm{m} \\
\text { genera } \\
\text { tor } \\
\text { using } \\
\text { a } \\
\text { permu } \\
\text { ted } \\
\text { block } \\
\text { stratifi } \\
\text { ed } \\
\text { rando } \\
\text { mizati } \\
\text { on }\end{array}$ & $41 / 41$ & $\begin{array}{l}37(8) / \\
34(9)\end{array}$ & $\begin{array}{l}24 \mathrm{M} \\
17 \mathrm{~F} / 27 \\
\mathrm{M} \\
14 \mathrm{~F}\end{array}$ & $\begin{array}{l}\text { Sympt } \\
\text { omatic } \\
\text { mandi } \\
\text { bular } \\
\text { molars }\end{array}$ & $\begin{array}{l}\text { Cold } \\
\text { tests } \\
\text { Elect } \\
\text { ric } \\
\text { pulp } \\
\text { tests }\end{array}$ & No/- & $\begin{array}{l}4 \% \\
\text { Artica } \\
\text { ine } \\
\text { with } \\
1: 100 \\
, 000 \\
\text { epine } \\
\text { phrin } \\
\text { e }\end{array}$ & $\begin{array}{l}2 \% \\
\text { Lidoc } \\
\text { aine } \\
\text { with } \\
1: 80,0 \\
00 \\
\text { epinep } \\
\text { hrine }\end{array}$ & $\begin{array}{l}\text { Supple } \\
\text { mentar } \\
\text { y } \\
\text { intralig } \\
\text { amenta } \\
\text { ry } \\
\text { injectio } \\
\text { ns after } \\
\text { IANB } \\
\text { failure }\end{array}$ & $\begin{array}{l}\text { Supple } \\
\text { mentar } \\
\text { y } \\
\text { intralig } \\
\text { amenta } \\
\text { ry } \\
\text { injectio } \\
\text { ns after } \\
\text { IANB } \\
\text { failure }\end{array}$ & 0.6 & 0.6 & 5 & $\begin{array}{l}\text { Success } \\
\text { of } \\
\text { anaesthe } \\
\text { sia }\end{array}$ & $\begin{array}{l}2 \% \\
\text { lidocaine } \\
\text { with } \\
1: 80,000 \\
\text { epinephri } \\
\text { ne and } \\
4 \% \\
\text { Articaine } \\
\text { with } \\
1: 100,000 \\
\text { epinephri } \\
\text { ne as } \\
\text { suppleme } \\
\text { ntary } \\
\text { intraligam } \\
\text { entary } \\
\text { injections } \\
\text { after an } \\
\text { unsuccess } \\
\text { ful } \\
\text { primary } \\
\text { IANB } \\
\text { improved } \\
\text { the } \\
\text { success } \\
\text { rates, with } \\
\text { no } \\
\text { significan } \\
\mathrm{t} \\
\text { difference }\end{array}$ \\
\hline
\end{tabular}




\begin{tabular}{|c|c|c|c|c|c|c|c|c|c|c|c|c|c|c|c|c|c|c|}
\hline & & & & & & & & & & & & & & & & & & $\begin{array}{l}\text { between } \\
\text { them. }\end{array}$ \\
\hline $\begin{array}{l}\text { Gha } \\
\text { zalg } \\
\text { oo A } \\
\text { et al } \\
(201 \\
9)^{23}\end{array}$ & Iran & $\begin{array}{l}\text { Prosp } \\
\text { ective } \\
\text { doubl } \\
\text { e- } \\
\text { blind } \\
\text { clinic } \\
\text { al } \\
\text { trial } \\
\text { study }\end{array}$ & $\begin{array}{l}\text { Rando } \\
\mathrm{m}\end{array}$ & $44 / 44$ & - & - & $\begin{array}{l}\text { Sympt } \\
\text { omatic } \\
\text { mandi } \\
\text { bular } \\
\text { first } \\
\text { molar }\end{array}$ & $\begin{array}{l}\text { Cold } \\
\text { test }\end{array}$ & - & $\begin{array}{l}4 \% \\
\text { Artica } \\
\text { ine } \\
\text { with } \\
1: 100 \\
, 000 \\
\text { epine } \\
\text { phrin } \\
\text { e }\end{array}$ & $\begin{array}{l}2 \% \\
\text { Lidoc } \\
\text { ainewi } \\
\text { th } \\
1: 100, \\
000 \\
\text { epinep } \\
\text { hrine }\end{array}$ & IANB & IANB & - & - & 15 & $\begin{array}{l}\text { Pain } \\
\text { levels at } \\
0,2,4 \text {, } \\
6,12 \text {, } \\
18, \\
36 \text {, and } \\
48 \mathrm{~h}\end{array}$ & $\begin{array}{l}\text { Articaine } \\
\text { for IANB } \\
\text { may } \\
\text { increase } \\
\text { post-root } \\
\text { canal } \\
\text { treatment } \\
\text { comfort } \\
\text { than } \\
\text { lidocaine }\end{array}$ \\
\hline $\begin{array}{l}\text { Lok } \\
\text { hand } \\
\text { e P } \\
\text { et al } \\
(201 \\
9)^{24}\end{array}$ & $\begin{array}{l}\text { Indi } \\
\text { a }\end{array}$ & $\begin{array}{l}\text { Singl } \\
\mathrm{e} \\
\text { blinde } \\
\mathrm{d} \\
\text { rando } \\
\text { mized } \\
\text { clinic } \\
\text { al } \\
\text { trial }\end{array}$ & $\begin{array}{l}\text { Conve } \\
\text { nience }\end{array}$ & $30 / 30$ & $\begin{array}{l}\text { Above } 18 \\
\text { years }\end{array}$ & - & $\begin{array}{l}\text { Sympt } \\
\text { omatic } \\
\text { mandi } \\
\text { bular } \\
\text { molar }\end{array}$ & - & $\mathrm{No} /-$ & $\begin{array}{l}4 \% \\
\text { Artica } \\
\text { ine } \\
(1: 10 \\
0000 \\
\text { adren } \\
\text { aline })\end{array}$ & $\begin{array}{l}2 \% \\
\text { Lidoc } \\
\text { aine } \\
(1: 800 \\
00 \\
\text { adrena } \\
\text { line) }\end{array}$ & $\begin{array}{l}\text { BI } \\
\text { combin } \\
\text { ed with } \\
\text { intralig } \\
\text { amenta } \\
\text { ry } \\
\text { injectio } \\
\text { n }\end{array}$ & $\begin{array}{l}\text { BI } \\
\text { combin } \\
\text { ed with } \\
\text { intralig } \\
\text { amenta } \\
\text { ry } \\
\text { injectio } \\
n\end{array}$ & $\begin{array}{l}1.8+ \\
0.2\end{array}$ & $\begin{array}{l}1.8 \\
+ \\
0.2\end{array}$ & 5 & $\begin{array}{l}\text { Anaesth } \\
\text { esia } \\
\text { success }\end{array}$ & $\begin{array}{l}\text { BI with } \\
4 \% \\
\text { Articaine } \\
\text { along } \\
\text { with } \\
\text { suppleme } \\
\text { ntal } \\
\text { injection } \\
\text { (intraliga } \\
\text { mentary) } \\
\text { increased } \\
\text { anaestheti } \\
\text { c success } \\
\text { rates. } \\
\end{array}$ \\
\hline $\begin{array}{l}\text { Mart } \\
\text { ínez } \\
\text { AM } \\
\text { et al } \\
(201 \\
8)^{25}\end{array}$ & $\begin{array}{l}\text { Col } \\
\text { omb } \\
\text { ia }\end{array}$ & $\begin{array}{l}\text { Rand } \\
\text { omize } \\
\text { d, } \\
\text { doubl } \\
\text { e- } \\
\text { blind, } \\
\text { parall } \\
\text { el- } \\
\text { contr } \\
\text { olled } \\
\text { clinic } \\
\text { al } \\
\text { trial }\end{array}$ & $\begin{array}{l}\text { Block } \\
\text { rando } \\
\text { mizati } \\
\text { on }\end{array}$ & $18 / 18$ & Over 18 & - & $\begin{array}{l}\text { Lower } \\
\text { molars }\end{array}$ & $\begin{array}{l}\text { Vital } \\
\text { omet } \\
\text { er }\end{array}$ & - & $\begin{array}{l}4 \% \\
\text { Artica } \\
\text { ine } \\
\text { with } \\
1: 100 \\
, 000 \\
\text { epine } \\
\text { phrin } \\
\text { e }\end{array}$ & $\begin{array}{l}2 \% \\
\text { Lidoc } \\
\text { aine } \\
\text { with } \\
1: 80,0 \\
00 \\
\text { epinep } \\
\text { hrine }\end{array}$ & IANB & IANB & 1.8 & 1.8 & 10 & $\begin{array}{l}\text { Anaesth } \\
\text { esia } \\
\text { success }\end{array}$ & $\begin{array}{l}\text { No } \\
\text { statisticall } \\
\mathrm{y} \\
\text { significan } \\
\mathrm{t} \\
\text { difference } \\
\mathrm{s} \text { were } \\
\text { found in } \\
\text { the } \\
\text { anaestheti } \\
\mathrm{c} \text { efficacy } \\
\text { of } 2 \% \\
\text { lidocaine } \\
\text { and } 4 \% \\
\text { Articaine } \\
\text { in lower } \\
\text { molars } \\
\text { with vital } \\
\text { pulp. } \\
\text { Articaine } \\
\text { showed a }\end{array}$ \\
\hline
\end{tabular}




\begin{tabular}{|c|c|c|c|c|c|c|c|c|c|c|c|c|c|c|c|c|c|c|}
\hline & & & & & & & & & & & & & & & & & & $\begin{array}{l}\text { better } \\
\text { anaestheti } \\
\text { c success } \\
\text { rate. }\end{array}$ \\
\hline $\begin{array}{l}\text { Shap } \\
\text { iro } \\
\text { et al } \\
(201 \\
8)^{26}\end{array}$ & $\begin{array}{l}\text { Unit } \\
\text { ed } \\
\text { Stat } \\
\text { es }\end{array}$ & $\begin{array}{l}\text { Prosp } \\
\text { ective } \\
\text { ' } \\
\text { rando } \\
\text { mized } \\
\text { doubl } \\
\text { e- } \\
\text { blind }\end{array}$ & $\begin{array}{l}\text { Block } \\
\text { rando } \\
\text { mizati } \\
\text { on }\end{array}$ & $76 / 73$ & $37-41$ & $\begin{array}{l}41 \mathrm{M}, 35 \\
\mathrm{~F} / \\
32 \mathrm{M}, 41 \\
\mathrm{~F}\end{array}$ & $\begin{array}{l}\text { Sympt } \\
\text { omatic } \\
\text { mandi } \\
\text { bular } \\
\text { molar }\end{array}$ & $\begin{array}{l}\text { Cold } \\
\text { testin } \\
\mathrm{g} \\
\text { with } \\
\text { Endo } \\
\text {-Ice }\end{array}$ & $\begin{array}{l}\mathrm{No} / \mathrm{Ye} \\
\mathrm{s}\end{array}$ & $\begin{array}{l}4 \% \\
\text { Artica } \\
\text { ine } \\
\text { with } \\
1: 100 \\
, 000 \\
\text { epine } \\
\text { phrin } \\
\text { e }\end{array}$ & $\begin{array}{l}2 \% \\
\text { Lidoc } \\
\text { aine } \\
\text { with } \\
1: 100, \\
000 \\
\text { epinep } \\
\text { hrine }\end{array}$ & $\begin{array}{l}\text { Supple } \\
\text { mentar } \\
\text { y } \\
\text { BI after } \\
\text { IANB } \\
\text { failure }\end{array}$ & $\begin{array}{l}\text { Supple } \\
\text { mentar } \\
\text { y } \\
\text { BI after } \\
\text { IANB } \\
\text { failure }\end{array}$ & 1.7 & 1.7 & 5 & $\begin{array}{l}\text { Success } \\
\text { ful } \\
\text { infiltrati } \\
\text { on } \\
\text { anaesthe } \\
\text { sia }\end{array}$ & $\begin{array}{l}\text { Suppleme } \\
\text { ntal BI } \\
\text { with } 4 \% \\
\text { Articaine } \\
\text { and } 2 \% \\
\text { lidocaine } \\
\text { was found } \\
\text { to have } \\
\text { comparab } \\
\text { le success } \\
\text { in the first } \\
\text { molar } \\
\text { region. BI } \\
\text { with } 4 \% \\
\text { Articaine } \\
\text { was } \\
\text { significan } \\
\text { tly more } \\
\text { effective } \\
\text { than } 2 \% \\
\text { lidocaine } \\
\text { for } \\
\text { mandibul } \\
\text { ar second } \\
\text { molars } \\
\text { with } \\
\text { irreversibl } \\
\text { e pulpitis. }\end{array}$ \\
\hline
\end{tabular}




\begin{tabular}{|c|c|c|c|c|c|c|c|c|c|c|c|c|c|c|c|c|c|c|}
\hline $\begin{array}{l}\text { Agg } \\
\text { arwa } \\
1 \mathrm{~V} \\
\text { et al } \\
(201 \\
7)^{27}\end{array}$ & $\begin{array}{l}\text { Indi } \\
\mathrm{a}\end{array}$ & $\begin{array}{l}\text { Prosp } \\
\text { ective } \\
\text { ' } \\
\text { doubl } \\
\text { e- } \\
\text { blind } \\
\text { clinic } \\
\text { al } \\
\text { study }\end{array}$ & $\begin{array}{l}\text { Rando } \\
\text { mized } \\
\text { using } \\
\text { an } \\
\text { online } \\
\text { rando } \\
\text { m } \\
\text { genera } \\
\text { tor }\end{array}$ & $32 / 31$ & $\begin{array}{l}34(6.5) / \\
37(8.3)\end{array}$ & $\begin{array}{l}16 \mathrm{M}, \\
14 \mathrm{~F} / \\
22 \mathrm{M}, 9 \mathrm{~F}\end{array}$ & $\begin{array}{l}\text { Mandi } \\
\text { bular } \\
\text { molar }\end{array}$ & $\begin{array}{l}\text { Pulp } \\
\text { sensi } \\
\text { tivity } \\
\text { tests }\end{array}$ & $\mathrm{No} /-$ & $\begin{array}{l}4 \% \\
\text { Artica } \\
\text { ine } \\
\text { with } \\
1: 100 \\
, 000 \\
\text { epine } \\
\text { phrin } \\
\text { e }\end{array}$ & $\begin{array}{l}2 \% \\
\text { Lidoc } \\
\text { aine } \\
\text { with } \\
1: 200, \\
000 \\
\text { epinep } \\
\text { hrine }\end{array}$ & IANB & IANB & $\begin{array}{l}\text { Stand } \\
\text { ard } \\
4 \% \\
\text { Artica } \\
\text { ine } \\
\text { cartri } \\
\text { dge/ } \\
1.8 \\
\mathrm{~mL}\end{array}$ & 1.8 & 15 & $\begin{array}{l}\text { Success } \\
\text { of } \\
\text { anaesthe } \\
\text { sia }\end{array}$ & $\begin{array}{l}\text { The } 2 \% \\
\text { lidocaine } \\
\text { solution } \\
\text { used for } \\
\text { IANB had } \\
\text { similar } \\
\text { success } \\
\text { rates } \\
\text { when } \\
\text { compared } \\
\text { with } 4 \% \\
\text { Articaine }\end{array}$ \\
\hline $\begin{array}{l}\text { Ume } \\
\text { sh G } \\
\text { et al } \\
(201 \\
7)^{28}\end{array}$ & $\begin{array}{l}\text { Indi } \\
\mathrm{a}\end{array}$ & $\begin{array}{l}\text { Prosp } \\
\text { ective } \\
\text {, } \\
\text { rando } \\
\text { mized } \\
\text { triple- } \\
\text { blind } \\
\text { study }\end{array}$ & $\begin{array}{l}\text { Rando } \\
\text { mly- } \\
\text { Seque } \\
\text { nce } \\
\text { genera } \\
\text { ted by } \\
\text { compu } \\
\text { terized } \\
\text { permu } \\
\text { tted } \\
\text { block }\end{array}$ & $30 / 30$ & $18-65$ & - & $\begin{array}{l}\text { Sympt } \\
\text { omatic } \\
\text { mandi } \\
\text { bular } \\
\text { molars }\end{array}$ & $\begin{array}{l}\text { Elect } \\
\text { ric } \\
\text { pulp } \\
\text { test } \\
\text { Ther } \\
\text { mal } \\
\text { test }\end{array}$ & - & $\begin{array}{l}4 \\
\% \\
\text { Artica } \\
\text { ine } \\
\text { with } \\
1: 1 \\
, \\
00,00 \\
0 \\
\text { Adren } \\
\text { aline }\end{array}$ & $\begin{array}{l}2 \\
\% \\
\text { Ligno } \\
\text { caine } \\
\text { with } \\
1: \\
80,00 \\
0 \\
\text { Adren } \\
\text { aline }\end{array}$ & IANB & IANB & 6 & 3 & - & $\begin{array}{l}\text { Pre- } \\
\text { post- } \\
\text { operativ } \\
\text { e pain }\end{array}$ & 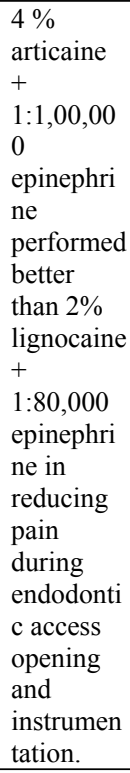 \\
\hline $\begin{array}{l}\text { Alle } \\
\text { grett } \\
\text { i CE } \\
\text { et al } \\
(201 \\
6)^{29}\end{array}$ & $\begin{array}{l}\text { Bra } \\
\text { zil }\end{array}$ & $\begin{array}{l}\begin{array}{l}\text { Prosp } \\
\text { ective }\end{array} \\
\text { rando } \\
\text { mized } \\
\text { doubl } \\
\text { e- } \\
\text { blind } \\
\text { clinic } \\
\text { al } \\
\text { study }\end{array}$ & $\begin{array}{l}\text { Simpl } \\
\mathrm{e} \\
\text { rando } \\
\mathrm{m}\end{array}$ & $22 / 22$ & $\begin{array}{l}28.7 / \\
30.3\end{array}$ & $\begin{array}{l}10 \mathrm{M}, 12 \\
\mathrm{~F} / 9 \mathrm{M}, 13 \\
\mathrm{~F}\end{array}$ & $\begin{array}{l}\text { Sympt } \\
\text { omatic } \\
\text { first or } \\
\text { second } \\
\text { molars }\end{array}$ & $\begin{array}{l}\text { Elect } \\
\text { ric } \\
\text { pulp } \\
\text { test } \\
\text { Cold } \\
\text { testin } \\
\text { g } \\
\text { with } \\
\text { Endo } \\
- \\
\text { Frost }\end{array}$ & $\mathrm{No} /-$ & $\begin{array}{l}4 \% \\
\text { Artica } \\
\text { ine } \\
\text { with } \\
1: 100 \\
, 000 \\
\text { epine } \\
\text { phrin } \\
\text { e }\end{array}$ & $\begin{array}{l}2 \% \\
\text { Lidoc } \\
\text { aine } \\
\text { with } \\
1: 100, \\
000 \\
\text { epinep } \\
\text { hrine }\end{array}$ & $\begin{array}{l}\text { Standar } \\
\text { d } \\
\text { IANB }\end{array}$ & $\begin{array}{l}\text { Standar } \\
\text { d } \\
\text { IANB }\end{array}$ & 3.6 & 3.6 & $\begin{array}{l}14 \text { to } \\
16\end{array}$ & $\begin{array}{l}\text { Success } \\
\text { of } \\
\text { anaesthe } \\
\text { sia }\end{array}$ & 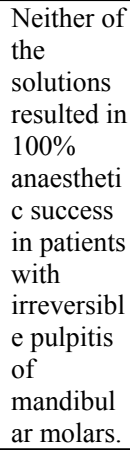 \\
\hline
\end{tabular}




\begin{tabular}{|c|c|c|c|c|c|c|c|c|c|c|c|c|c|c|c|c|c|c|}
\hline $\begin{array}{l}\text { Hoss } \\
\text { eini } \\
\text { HR } \\
\text { et al } \\
(201 \\
6)^{30}\end{array}$ & Iran & $\begin{array}{l}\text { Prosp } \\
\text { ective } \\
\text { rando } \\
\text { mized } \\
\text { doubl } \\
\text { e- } \\
\text { blind } \\
\text { study }\end{array}$ & $\begin{array}{l}\text { Simpl } \\
\mathrm{e} \\
\text { rando } \\
\mathrm{m}\end{array}$ & $25 / 25$ & - & - & $\begin{array}{l}\text { Asym } \\
\text { ptomat } \\
\text { ic first } \\
\text { maxill } \\
\text { ary } \\
\text { molar }\end{array}$ & $\begin{array}{l}\text { Eelec } \\
\text { tric } \\
\text { Pulp } \\
\text { Teste } \\
\mathrm{r} \\
\\
\text { Cold } \\
\text { tests }\end{array}$ & $\mathrm{No} /-$ & $\begin{array}{l}4 \% \\
\text { Artica } \\
\text { ine } \\
\text { with } \\
1: 100 \\
000 \\
\text { epine } \\
\text { phrin } \\
\text { e }\end{array}$ & $\begin{array}{l}2 \% \\
\text { Lidoc } \\
\text { aine } \\
\text { with } \\
1: 800 \\
00 \\
\text { epinep } \\
\text { hrine }\end{array}$ & $\mathrm{BI}$ & BI & 1.8 & 1.8 & 5 & $\begin{array}{l}\text { Success } \\
\text { of } \\
\text { anaesthe } \\
\text { sia }\end{array}$ & $\begin{array}{l}\text { The type } \\
\text { of } \\
\text { anaestheti } \\
\text { c solution } \\
\text { had no } \\
\text { significan } \\
\mathrm{t} \\
\text { influence } \\
\text { on the } \\
\text { success } \\
\text { rate of } \\
\text { anaesthesi } \\
\text { a with } \\
\text { Articaine } \\
\text { and } \\
\text { lidocaine } \\
\text { being } \\
\text { similarly } \\
\text { effective. }\end{array}$ \\
\hline $\begin{array}{l}\text { Sara } \\
\text { f SP } \\
\text { et al } \\
(201 \\
6)^{31}\end{array}$ & $\begin{array}{l}\text { Indi } \\
\mathrm{a}\end{array}$ & $\begin{array}{l}\text { Clinic } \\
\text { al } \\
\text { study }\end{array}$ & $\begin{array}{l}\text { Rando } \\
\mathrm{m}\end{array}$ & $20 / 20$ & - & - & $\begin{array}{l}\text { Sympt } \\
\text { omatic } \\
\text { maxill } \\
\text { ary } \\
\text { anterio } \\
\text { rs and } \\
\text { premo } \\
\text { lars }\end{array}$ & $\begin{array}{l}\text { Elect } \\
\text { ric } \\
\text { pulp } \\
\text { tester }\end{array}$ & - & $\begin{array}{l}\text { Grou } \\
\text { p I: } \\
\text { Artica } \\
\text { ine } \\
\mathrm{HCl} \\
4 \% \\
\text { with } \\
1: 100 \\
, 000 \\
\text { adren } \\
\text { aline } \\
\text { Grou } \\
\text { p II: } \\
\text { Artica } \\
\text { ine } \\
\mathrm{HCl} \\
4 \% \\
\text { with } \\
1: 100 \\
, 000 \\
\text { adren } \\
\text { aline }\end{array}$ & $\begin{array}{l}\text { Group } \\
\text { III: } \\
\text { Lidoc } \\
\text { aine } \\
\mathrm{HCl} \\
2 \% \\
\text { with } \\
1: 80,0 \\
00 \\
\text { adrena } \\
\text { line } \\
\text { Group } \\
\text { IV: } \\
\text { Lidoc } \\
\text { aine } \\
\mathrm{HCl} \\
2 \% \\
\text { with } \\
1: 80,0 \\
00 \\
\text { adrena } \\
\text { line }\end{array}$ & $\begin{array}{l}\text { Group } \\
\text { I: } \\
\text { Anterio } \\
\mathrm{r} \\
\text { middle } \\
\text { superio } \\
\mathrm{r} \\
\text { alveola } \\
\mathrm{r} \text { nerve } \\
\text { block } \\
\\
\text { Group } \\
\text { II: } \\
\text { Infraor } \\
\text { bital } \\
\text { nerve } \\
\text { block }\end{array}$ & $\begin{array}{l}\text { Group } \\
\text { III: } \\
\text { Anterio } \\
\mathrm{r} \\
\text { middle } \\
\text { superio } \\
\mathrm{r} \\
\text { alveola } \\
\mathrm{r} \text { nerve } \\
\text { block } \\
\text { Group } \\
\text { IV: } \\
\text { Infraor } \\
\text { bital } \\
\text { nerve } \\
\text { block }\end{array}$ & $\begin{array}{l}\text { Grou } \\
\text { p I: } \\
0.6- \\
1.4 \\
\\
\text { Grou } \\
\text { p II: } \\
0.9- \\
1.2\end{array}$ & $\begin{array}{l}\text { Gr } \\
\text { oup } \\
\text { III: } \\
0.6 \\
- \\
1.4 \\
\\
\text { Gr } \\
\text { oup } \\
\text { IV: } \\
0.9 \\
- \\
1.2\end{array}$ & 30 & $\begin{array}{l}\begin{array}{l}\text { Onset of } \\
\text { anaesthe } \\
\text { sia }\end{array} \\
\text { Pain } \\
\text { assessm } \\
\text { ent }\end{array}$ & $\begin{array}{l}\text { Articaine } \\
4 \% \\
\text { proved to } \\
\text { be more } \\
\text { efficaciou } \\
\mathrm{s} \text { than } \\
\text { lidocaine } \\
2 \% \text {, and } \\
\text { AMSAN } \\
\text { B was } \\
\text { more } \\
\text { advantage } \\
\text { ous than } \\
\text { IONB in } \\
\text { securing } \\
\text { anaesthesi } \\
\text { a of } \\
\text { maxillary } \\
\text { anteriors } \\
\text { and } \\
\text { premolars }\end{array}$ \\
\hline
\end{tabular}




\begin{tabular}{|c|c|c|c|c|c|c|c|c|c|c|c|c|c|c|c|c|c|c|}
\hline $\begin{array}{l}\text { Zain } \\
M \text { et } \\
\text { al } \\
(201 \\
6)^{32}\end{array}$ & $\begin{array}{l}\text { Paki } \\
\text { stan }\end{array}$ & $\begin{array}{l}\text { Prosp } \\
\text { ective } \\
\text { and } \\
\text { rando } \\
\text { mized } \\
\text { clinic } \\
\text { al } \\
\text { trial }\end{array}$ & $\begin{array}{l}\text { Lotter } \\
\text { y } \\
\text { metho } \\
\text { d }\end{array}$ & $78 / 78$ & $\begin{array}{l}31.46(10 . \\
99)\end{array}$ & $\begin{array}{l}46 \mathrm{M}, 32 \\
\mathrm{~F} / 46 \mathrm{M}, \\
32 \mathrm{~F}\end{array}$ & $\begin{array}{l}\text { Sympt } \\
\text { omatic } \\
\text { mandi } \\
\text { bular } \\
1 \text { st } \\
\text { molar }\end{array}$ & yes & No/- & $\begin{array}{l}\% \\
\text { Artica } \\
\text { ine } \\
\text { with } \\
1: 100 \\
, 000 \\
\text { epine } \\
\text { phrin } \\
\text { e }\end{array}$ & $\begin{array}{l}\% \\
\text { lidocai } \\
\text { ne } \\
\text { with } \\
1: 100 \\
000\end{array}$ & BI & IANB & 1.8 & 1.8 & 10 & $\begin{array}{l}\text { Success } \\
\text { of } \\
\text { anaesthe } \\
\text { sia }\end{array}$ & $\begin{array}{l}\% \\
\text { Articaine } \\
\text { BI can be } \\
\text { considere } \\
\text { d a viable } \\
\text { alternativ } \\
\text { e to } 2 \% \\
\text { lidocaine } \\
\text { IANB in } \\
\text { securing } \\
\text { successful } \\
\text { pulpal } \\
\text { anaesthesi } \\
\text { a for } \\
\text { endodonti } \\
\mathrm{c} \text { therapy. }\end{array}$ \\
\hline $\begin{array}{l}\text { Mon } \\
\text { teiro } \\
\text { MR } \\
\text { et al } \\
(201 \\
5)^{33}\end{array}$ & $\begin{array}{l}\text { Bra } \\
\text { zil }\end{array}$ & $\begin{array}{l}\text { Prosp } \\
\text { ective } \\
\text { and } \\
\text { rando } \\
\text { mized } \\
\text { clinic } \\
\text { al } \\
\text { trial }\end{array}$ & $\begin{array}{l}\text { Rando } \\
\mathrm{m} \\
\text { numbe } \\
\text { rs }\end{array}$ & $30 / 20$ & $\begin{array}{l}28(13.8) / \\
33.5(16.5)\end{array}$ & $\begin{array}{l}5 \mathrm{M}, 25 \mathrm{~F} / \\
4 \mathrm{M}, 16 \mathrm{~F}\end{array}$ & $\begin{array}{l}\text { Sympt } \\
\text { omatic } \\
\text { mandi } \\
\text { bular } \\
\text { molars }\end{array}$ & $\begin{array}{l}\text { Cold } \\
\text { tests }\end{array}$ & $\begin{array}{l}\text { No/ } \\
\text { Yes }\end{array}$ & $\begin{array}{l}4 \% \\
\text { Artica } \\
\text { ine } \\
\text { with } \\
1: \\
100 \\
000 \\
\text { epine } \\
\text { phrin } \\
\text { e }\end{array}$ & $\begin{array}{l}2 \% \\
\text { Lidoc } \\
\text { aine } \\
\text { with } \\
1: 100 \\
000 \\
\text { epinep } \\
\text { hrine }\end{array}$ & BIs & $\begin{array}{l}\text { IANB } \\
\text { injectio } \\
\text { ns }\end{array}$ & 1.8 & 1.8 & 10 & $\begin{array}{l}\text { Success } \\
\text { of } \\
\text { anaesthe } \\
\text { sia }\end{array}$ & $\begin{array}{l}\text { Single } \\
\text { anaesthesi } \\
\text { a } \\
\text { technique } \\
\mathrm{s} \text { (IANB } \\
\text { or BI) } \\
\text { were not } \\
\text { able to } \\
\text { achieve } \\
\text { pain-free } \\
\text { emergenc } \\
\text { y } \\
\text { endodonti } \\
\mathrm{c} \\
\text { treatment. }\end{array}$ \\
\hline $\begin{array}{l}\text { Rajp } \\
\text { ut F } \\
\text { et al } \\
(201 \\
5)^{34}\end{array}$ & $\begin{array}{l}\text { Paki } \\
\text { stan }\end{array}$ & $\begin{array}{l}\text { Prosp } \\
\text { ective } \\
, \\
\text { rando } \\
\text { mized } \\
\text { clinic } \\
\text { al } \\
\text { trial }\end{array}$ & $\begin{array}{l}\text { Simpl } \\
\text { e } \\
\text { rando } \\
\text { mized }\end{array}$ & $30 / 30$ & $18-65$ & - & $\begin{array}{l}\text { Sympt } \\
\text { omatic } \\
\text { mandi } \\
\text { bular } \\
\text { first } \\
\text { molar }\end{array}$ & - & - & $\begin{array}{l}4 \% \\
\text { Artica } \\
\text { ine } \\
\text { with } \\
1: 100 \\
, 000 \\
\text { epine } \\
\text { phrin } \\
\text { e }\end{array}$ & $\begin{array}{l}2 \% \\
\text { Lidoc } \\
\text { aine } \\
\text { with } \\
1: 200 \text {, } \\
000 \\
\text { epinep } \\
\text { hrine }\end{array}$ & $\begin{array}{l}\text { Standar } \\
\text { d BI }\end{array}$ & $\begin{array}{l}\text { Standar } \\
\text { d } \\
\text { IANB }\end{array}$ & 1.7 & 1.8 & 10 & $\begin{array}{l}\text { Success } \\
\text { of } \\
\text { anaesthe } \\
\text { sia }\end{array}$ & $\begin{array}{l}4 \% \\
\text { Articaine } \\
\text { with } \\
1: 100,000 \\
\text { epinephri } \\
\text { ne can be } \\
\text { considere } \\
\text { d as an } \\
\text { alternativ } \\
\text { e for } \\
\text { pulpal } \\
\text { anaesthesi } \\
\text { a in } \\
\text { mandibul } \\
\text { ar first } \\
\text { molar } \\
\text { with } \\
\text { irreversibl } \\
\text { e pulpitis. }\end{array}$ \\
\hline
\end{tabular}




\begin{tabular}{|c|c|c|c|c|c|c|c|c|c|c|c|c|c|c|c|c|c|c|}
\hline $\begin{array}{l}\text { Ahm } \\
\text { ad } \\
\text { ZH } \\
\text { et al } \\
(201 \\
4)^{35}\end{array}$ & $\begin{array}{l}\text { Riy } \\
\text { adh, } \\
\text { Sau } \\
\text { di } \\
\text { Ara } \\
\text { bia }\end{array}$ & $\begin{array}{l}\text { Non- } \\
\text { rando } \\
\text { mized } \\
\text { contr } \\
\text { ol } \\
\text { trial }\end{array}$ & - & $15 / 15$ & $18-40$ & - & $\begin{array}{l}\text { Sympt } \\
\text { omatic } \\
\text { mandi } \\
\text { bular } \\
\text { teeth }\end{array}$ & $\begin{array}{l}\text { Cold } \\
\text { testin } \\
\mathrm{g} \\
\text { with } \\
\text { an } \\
\text { ice } \\
\text { stick } \\
\\
\text { Elect } \\
\text { ric } \\
\text { pulp } \\
\text { tester }\end{array}$ & $\mathrm{No} /-$ & $\begin{array}{l}4 \% \\
\text { Artica } \\
\text { ine } \\
\text { with } \\
1: 100 \\
000 \\
\text { epine } \\
\text { phrin } \\
\text { e }\end{array}$ & 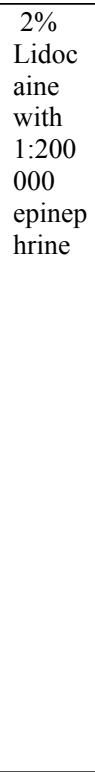 & $\begin{array}{l}\text { Standar } \\
\text { d } \\
\text { IANB }\end{array}$ & $\begin{array}{l}\text { Standar } \\
\mathrm{d} \\
\text { IANB }\end{array}$ & - & - & 15 & $\begin{array}{l}\text { Success } \\
\text { of } \\
\text { anaesthe } \\
\text { sia }\end{array}$ & $\begin{array}{l}4 \% \\
\text { Articaine } \\
\text { with } \\
1: 100,000 \\
\text { epinephri } \\
\text { ne } \\
\text { showed } \\
\text { better } \\
\text { anaestheti } \\
\text { c effect } \\
\text { when } \\
\text { administe } \\
\text { red as } \\
\text { inferior } \\
\text { alveolar } \\
\text { nerve } \\
\text { block as } \\
\text { compared } \\
\text { to } 2 \% \\
\text { lidocaine } \\
\text { with } \\
1: 200,000 \\
\text { epinephri } \\
\text { ne. }\end{array}$ \\
\hline $\begin{array}{l}\mathrm{Nab} \\
\text { eel } \\
\mathrm{M} \text { et } \\
\mathrm{al} \\
(201 \\
4)^{36}\end{array}$ & $\begin{array}{l}\text { Paki } \\
\text { stan }\end{array}$ & $\begin{array}{l}\text { Rand } \\
\text { omize } \\
\mathrm{d} \\
\text { clinic } \\
\text { al } \\
\text { trial }\end{array}$ & $\begin{array}{l}\text { Comp } \\
\text { uter- } \\
\text { genera } \\
\text { ted list } \\
\text { of } \\
\text { rando } \\
\text { m } \\
\text { numbe } \\
\text { rs }\end{array}$ & $38 / 38$ & & $\begin{array}{l}15 \mathrm{M}, 23 \\
\mathrm{~F} / 18 \mathrm{M}, \\
20 \mathrm{~F}\end{array}$ & $\begin{array}{l}\text { Maxill } \\
\text { ary } \\
\text { first } \\
\text { premo } \\
\text { lars }\end{array}$ & - & - & $\begin{array}{l}4 \% \\
\text { Atrica } \\
\text { ine } \\
\text { with } \\
1: 100 \\
, 000 \\
\text { epine } \\
\text { phrin } \\
\text { e }\end{array}$ & $\begin{array}{l}2 \% \\
\text { Lidoc } \\
\text { aine } \\
\text { with } \\
1: 100 \text {, } \\
000 \\
\text { epinep } \\
\text { hrine }\end{array}$ & BI & BI & 1.7 & 1.7 & 5 & $\begin{array}{l}\text { Success } \\
\text { ful } \\
\text { infiltrati } \\
\text { on } \\
\text { anaesthe } \\
\text { sia }\end{array}$ & $\begin{array}{l}\text { The } \\
\text { anaestheti } \\
\text { c efficacy } \\
\text { of } \\
\text { Articaine } \\
\text { is } \\
\text { comparab } \\
\text { le to that } \\
\text { of } \\
\text { Lidocaine } \\
\text { in } \\
\text { subjects } \\
\text { with acute } \\
\text { irreversibl } \\
\text { e pulpitis } \\
\text { of } \\
\text { maxillary } \\
\text { teeth with } \\
\text { irreversibl } \\
\text { e pulpitis. }\end{array}$ \\
\hline
\end{tabular}




\begin{tabular}{|c|c|c|c|c|c|c|c|c|c|c|c|c|c|c|c|c|c|c|}
\hline $\begin{array}{l}\text { Rog } \\
\text { ers } \\
\text { BS } \\
\text { et al } \\
(201 \\
4)^{37}\end{array}$ & $\begin{array}{l}\text { Unit } \\
\text { ed } \\
\text { Stat } \\
\text { es }\end{array}$ & $\begin{array}{l}\text { Prosp } \\
\text { ective } \\
\text { doubl } \\
\text { e- } \\
\text { - } \\
\text { blind, } \\
\text { rando } \\
\text { mized } \\
, \\
\text { contr } \\
\text { olled } \\
\text { clinic } \\
\text { al } \\
\text { trial }\end{array}$ & $\begin{array}{l}\text { Block } \\
\text { rando } \\
\text { mizati } \\
\text { on }\end{array}$ & $39 / 35$ & $\begin{array}{l}36(14) / 36 \\
(12)\end{array}$ & $\begin{array}{l}17 \mathrm{M}, 22 \\
\mathrm{~F} / 12 \mathrm{M}, \\
23 \mathrm{~F}\end{array}$ & $\begin{array}{l}\text { Sympt } \\
\text { omatic } \\
\text { mandi } \\
\text { bular } \\
\text { molar }\end{array}$ & $\begin{array}{l}\text { Cold } \\
\text { testin } \\
\mathrm{g} \\
\text { with } \\
\text { Endo } \\
\text {-Ice }\end{array}$ & $\begin{array}{l}\mathrm{No} / \mathrm{Ye} \\
\mathrm{s}\end{array}$ & $\begin{array}{l}\% \\
\text { Artica } \\
\text { ine } \\
\text { with } \\
1: 100 \\
, 000 \\
\text { epine } \\
\text { phrin } \\
\text { e }\end{array}$ & $\begin{array}{l}\% \\
\text { Lidoc } \\
\text { aine } \\
\text { with } \\
1: 100, \\
000 \\
\text { epinep } \\
\text { hrine }\end{array}$ & $\begin{array}{l}\text { Supple } \\
\text { mentar } \\
\text { y } \\
\text { BI after } \\
\text { IANB } \\
\text { failure }\end{array}$ & $\begin{array}{l}\text { Supple } \\
\text { mentar } \\
\text { y } \\
\text { BI after } \\
\text { IANB } \\
\text { failure }\end{array}$ & 1.7 & $\begin{array}{l}1.7 \\
-\end{array}$ & 5 & $\begin{array}{l}\text { Success } \\
\text { ful } \\
\text { infiltrati } \\
\text { on } \\
\text { anaesthe } \\
\text { sia }\end{array}$ & $\begin{array}{l}\text { Suppleme } \\
\text { ntal BI } \\
\text { with } \\
\text { Articaine } \\
\text { was } \\
\text { significan } \\
\text { tly more } \\
\text { effective } \\
\text { than } \\
\text { Lidocaine }\end{array}$ \\
\hline $\begin{array}{l}\text { Sood } \\
\text { R et } \\
\text { al } \\
(201 \\
4)^{38}\end{array}$ & $\begin{array}{l}\text { Indi } \\
\mathrm{a}\end{array}$ & $\begin{array}{l}\text { Prosp } \\
\text { ective } \\
\text { rando } \\
\text { mized } \\
\text { ' } \\
\text { doubl } \\
\text { e- } \\
\text { blind } \\
\text { clinic } \\
\text { al } \\
\text { study }\end{array}$ & $\begin{array}{l}\text { Not } \\
\text { menti } \\
\text { oned }\end{array}$ & $50 / 50$ & $\begin{array}{l}26.46 / 28.9 \\
0\end{array}$ & $\begin{array}{l}20 \mathrm{M} / 30 \\
\mathrm{~F}, \\
27 \mathrm{M} / 23 \mathrm{~F}\end{array}$ & $\begin{array}{l}\text { Mandi } \\
\text { bular } \\
\text { posteri } \\
\text { or } \\
\text { teeth }\end{array}$ & $\begin{array}{l}\text { Elect } \\
\text { ric } \\
\text { pulp } \\
\text { testin } \\
\mathrm{g} \\
\\
\text { Cold } \\
\text { testin } \\
\mathrm{g} \\
\text { using } \\
\text { Roek } \\
\text { o } \\
\text { Endo } \\
- \\
\text { Frost }\end{array}$ & $\begin{array}{l}\mathrm{No} / \mathrm{Ye} \\
\mathrm{s}\end{array}$ & $\begin{array}{l}4 \% \\
\text { Artica } \\
\text { ine } \\
\text { with } \\
1: 100 \\
, 000 \\
\text { epine } \\
\text { phrin } \\
\text { e }\end{array}$ & $\begin{array}{l}2 \% \\
\text { Lidoc } \\
\text { aine } \\
\text { with } \\
1: 80,0 \\
00 \\
\text { epinep } \\
\text { hrine }\end{array}$ & IANB & IANB & 1.8 & 1.8 & 10 & $\begin{array}{l}\text { Absence } \\
\text { /presenc } \\
\text { e of } \\
\text { pain }\end{array}$ & $\begin{array}{l}\text { No } \\
\text { difference } \\
\text { in the } \\
\text { efficacy } \\
\text { of both } \\
\text { the dental } \\
\text { anaestheti } \\
\text { c agents } \\
\text { in } \\
\text { controllin } \\
\text { g pain } \\
\text { during the } \\
\text { treatment } \\
\text { of } \\
\text { irreversibl } \\
\text { e pulpitis. }\end{array}$ \\
\hline $\begin{array}{l}\text { Ashr } \\
\text { af H } \\
\text { et al } \\
(201 \\
3)^{39}\end{array}$ & Iran & $\begin{array}{l}\text { Prosp } \\
\text { ective } \\
\text { rando } \\
\text { mized } \\
\text { doubl } \\
\text { e- } \\
\text { blind } \\
\text { study }\end{array}$ & $\begin{array}{l}\text { Rando } \\
\text { mized } \\
\text { using } \\
\text { rando } \\
\mathrm{m} \\
\text { allocat } \\
\text { ion } \\
\text { softwa } \\
\text { re }\end{array}$ & $58 / 58$ & $\begin{array}{l}37.9 \\
(10.0) / \\
32.5(8.7)\end{array}$ & $\begin{array}{l}24 \mathrm{M}, 27 \\
\mathrm{~F} / \\
23 \mathrm{M}, 28 \\
\mathrm{~F}\end{array}$ & $\begin{array}{l}\text { Sympt } \\
\text { omatic } \\
\text { first or } \\
\text { second } \\
\text { mandi } \\
\text { bular } \\
\text { molar }\end{array}$ & $\begin{array}{l}\text { Cold } \\
\text { testin } \\
\mathrm{g} \text { by } \\
\text { using } \\
\text { an } \\
\text { ice } \\
\text { stick }\end{array}$ & $\begin{array}{l}\mathrm{No} / \mathrm{Ye} \\
\mathrm{s}\end{array}$ & $\begin{array}{l}\% \\
\text { Artica } \\
\text { ine } \\
\text { with } \\
1: 100 \\
, 000 \\
\text { epine } \\
\text { phrin } \\
\text { e }\end{array}$ & $\begin{array}{l}\% \\
\text { Lidoc } \\
\text { aine } \\
\text { with } \\
1: 100 \text {, } \\
000 \\
\text { epinep } \\
\text { hrine }\end{array}$ & $\begin{array}{l}\text { Standar } \\
\mathrm{d} \\
\text { IANB } \\
\text { and } \\
\text { long } \\
\text { buccal } \\
\text { injectio } \\
\text { ns }\end{array}$ & $\begin{array}{l}\text { Standar } \\
\mathrm{d} \\
\text { IANB } \\
\text { and } \\
\text { long } \\
\text { buccal } \\
\text { injectio } \\
\text { ns }\end{array}$ & $\begin{array}{l}1.5+ \\
0.3\end{array}$ & $\begin{array}{l}1.5 \\
+ \\
0.3\end{array}$ & 5 & $\begin{array}{l}\text { Success } \\
\text { ful } \\
\text { infiltrati } \\
\text { on } \\
\text { anaesthe } \\
\text { sia }\end{array}$ & $\begin{array}{l}\text { Articaine } \\
\text { seems to } \\
\text { raise } \\
\text { anaestheti } \\
\text { c success } \\
\text { more } \\
\text { effectivel } \\
\mathrm{y} \\
\text { compared } \\
\text { with } \\
\text { lidocaine } \\
\text { after an } \\
\text { incomplet } \\
\text { e IANB is } \\
\text { suppleme } \\
\text { nted with } \\
\text { an } \\
\text { infiltratio } \\
\mathrm{n} \\
\text { injection }\end{array}$ \\
\hline
\end{tabular}




\begin{tabular}{|c|c|c|c|c|c|c|c|c|c|c|c|c|c|c|c|c|c|}
\hline & & & & & & & & & & & & & & & & & $\begin{array}{l}\text { by using } \\
\text { the same } \\
\text { anaestheti } \\
\text { c for both } \\
\text { injections } \\
\text { in teeth } \\
\text { with } \\
\text { irreversibl } \\
\text { e pulpitis. }\end{array}$ \\
\hline $\begin{array}{l}\text { Tort } \\
\text { ama } \\
\text { no } \\
\text { IP et } \\
\text { al } \\
(201 \\
3)^{40}\end{array}$ & $\begin{array}{l}\text { Bra } \\
\text { zil }\end{array}$ & $\begin{array}{l}\text { Prosp } \\
\text { ective } \\
\text {, } \\
\text { rando } \\
\text { mized } \\
\text { ' doubl } \\
\text { e- } \\
\text { blinde } \\
\text { d } \\
\text { clinic } \\
\text { al } \\
\text { study }\end{array}$ & $\begin{array}{l}\text { Rando } \\
\mathrm{m}\end{array}$ & $\begin{array}{l}20(10 \\
\text { each }) / 10\end{array}$ & - & \begin{tabular}{l|l} 
Asym \\
ptomat \\
ic \\
mandi \\
bular \\
posteri \\
or \\
molars
\end{tabular} & $\begin{array}{l}\text { Elect } \\
\text { ric } \\
\text { pulp } \\
\text { stimu } \\
\text { lator }\end{array}$ & No/- & $\begin{array}{l}\text { ARTI } \\
100- \\
4 \% \\
\text { Artica } \\
\text { ine } \\
\text { with } \\
1: 100 \\
, 000 \\
\text { epine } \\
\text { phrin } \\
\text { e }\end{array}$ & $\begin{array}{l}2 \% \\
\text { lidocai } \\
\text { ne } \\
\text { with } \\
1: 100 \text {, } \\
000 \\
\text { epinep } \\
\text { hrine }\end{array}$ & IANB & IANB & 1.8 & 1.8 & 10 & $\begin{array}{l}\text { Onset of } \\
\text { pulpal } \\
\text { anaesthe } \\
\text { sia }\end{array}$ & $\begin{array}{l}4 \% \\
\text { Articaine } \\
\text { with } \\
1: 100,000 \\
\text { epinephri } \\
\text { ne } \\
\text { exhibited } \\
\text { faster } \\
\text { onset and } \\
\text { also had } \\
\text { longest } \\
\text { duration } \\
\text { of pulpal } \\
\text { anaesthesi } \\
\text { a when } \\
\text { compared } \\
\text { with all } \\
\text { solutions } \\
\end{array}$ \\
\hline $\begin{array}{l}\text { Kan } \\
\text { aa D } \\
\text { et al } \\
(201 \\
2)^{41}\end{array}$ & $\begin{array}{l}\text { Unit } \\
\text { ed } \\
\text { Kin } \\
\text { gdo } \\
\text { m }\end{array}$ & $\begin{array}{l}\text { Doubl } \\
\text { e- } \\
\text { blind } \\
\text { rando } \\
\text { mized } \\
\text { trial }\end{array}$ & $\begin{array}{l}\text { Web- } \\
\text { based } \\
\text { progra } \\
\mathrm{m} \text { for } \\
\text { rando } \\
\text { mizati } \\
\text { on }\end{array}$ & $38 / 35$ & $\begin{array}{l}\text { Over } 16 \\
\text { years }\end{array}$ & $\begin{array}{l}\text { Maxill } \\
\text { ary } \\
\text { perma } \\
\text { nent } \\
\text { teeth }\end{array}$ & $\begin{array}{l}\text { Elect } \\
\text { ronic } \\
\text { pulp } \\
\text { tester }\end{array}$ & - & $\begin{array}{l}4 \% \\
\text { Artica } \\
\text { ine } \\
\text { with } \\
1: 100 \\
, 000 \\
\text { epine } \\
\text { phrin } \\
\text { e }\end{array}$ & $\begin{array}{l}2 \% \\
\text { lidocai } \\
\text { ne } \\
\text { hydro } \\
\text { chlori } \\
\text { de } \\
\text { and } \\
\text { epinep } \\
\text { hrine } \\
1: 80,0 \\
00\end{array}$ & $\mathrm{BI}$ & BI & 2 & 2 & 10 & $\begin{array}{l}\text { Success } \\
\text { ful } \\
\text { infiltrati } \\
\text { on } \\
\text { anaesthe } \\
\text { sia }\end{array}$ & $\begin{array}{l}\text { BIs with } \\
4 \% \\
\text { Articaine } \\
\text { with } \\
1: 100,000 \\
\text { epinephri } \\
\text { ne and } \\
2 \% \\
\text { lidocaine } \\
\text { with } \\
1: 80,000 \\
\text { epinephri } \\
\text { ne } \\
\text { produced } \\
\text { similar } \\
\text { levels of } \\
\text { successful } \\
\text { pulp } \\
\text { anaesthesi } \\
\text { a, similar } \\
\text { onset } \\
\text { times of } \\
\text { successful }\end{array}$ \\
\hline
\end{tabular}




\begin{tabular}{|c|c|c|c|c|c|c|c|c|c|c|c|c|c|c|c|c|c|c|}
\hline & & & & & & & & & & & & & & & & & & $\begin{array}{l}\text { pulp } \\
\text { anaesthesi } \\
\text { a, and } \\
\text { similar } \\
\text { levels of } \\
\text { pain-free } \\
\text { treatment } \\
\text { in patients } \\
\text { attending } \\
\text { with } \\
\text { irreversibl } \\
\text { e pulpitis } \\
\text { in the } \\
\text { maxilla. }\end{array}$ \\
\hline $\begin{array}{l}\text { Kan } \\
\text { aa D } \\
\text { et al } \\
(201 \\
2)^{42}\end{array}$ & $\begin{array}{l}\text { Unit } \\
\text { ed } \\
\text { Kin } \\
\text { gdo } \\
\mathrm{m}\end{array}$ & $\begin{array}{l}\text { Doubl } \\
\text { e- } \\
\text { blind } \\
\text { rando } \\
\text { mized } \\
\text { trial }\end{array}$ & $\begin{array}{l}\text { Web- } \\
\text { based } \\
\text { progra } \\
\text { m for } \\
\text { rando } \\
\text { mizati } \\
\text { on }\end{array}$ & $25 / 25$ & $\begin{array}{l}18 \text { or } \\
\text { older }\end{array}$ & - & $\begin{array}{l}\text { Mandi } \\
\text { bular } \\
\text { teeth }\end{array}$ & $\begin{array}{l}\text { Elect } \\
\text { ronic } \\
\text { pulp } \\
\text { tester }\end{array}$ & - & $\begin{array}{l}4 \% \\
\text { Artica } \\
\text { ine } \\
\text { HCL } \\
\text { with } \\
\text { epine } \\
\text { phrin } \\
\text { e } \\
1: 100 \\
, 000\end{array}$ & $\begin{array}{l}2 \% \\
\text { Lidoc } \\
\text { aine } \\
\text { HCL } \\
\text { with } \\
1: 80,0 \\
00 \\
\text { epinep } \\
\text { hrine }\end{array}$ & $\begin{array}{l}\text { Supple } \\
\text { mentar } \\
\text { y BI } \\
\text { after } \\
\text { IANB } \\
\text { failure }\end{array}$ & $\begin{array}{l}\text { Repeat } \\
\text { lidocai } \\
\text { ne } \\
\text { IANB } \\
\text { after } \\
\text { IANB } \\
\text { failure }\end{array}$ & 2.0 & 2.0 & 5 & $\begin{array}{l}\text { Success } \\
\text { ful } \\
\text { infiltrati } \\
\text { on } \\
\text { anaesthe } \\
\text { sia }\end{array}$ & $\begin{array}{l}\text { BI of } 4 \% \\
\text { Articaine } \\
\text { with } \\
\text { epinephri } \\
\text { ne } \\
\text { allowed } \\
\text { more } \\
\text { pain-free } \\
\text { treatments } \\
\text { than } \\
\text { repeat } \\
\text { IANB } \\
\text { injections } \\
\text { for } \\
\text { patients } \\
\text { experienci } \\
\text { ng } \\
\text { irreversibl } \\
\text { e pulpitis } \\
\text { in } \\
\text { mandibul } \\
\text { ar } \\
\text { permanen } \\
\text { t teeth. }\end{array}$ \\
\hline $\begin{array}{l}\text { Subb } \\
\text { iya } \\
\text { A et } \\
\text { al } \\
(201 \\
2)^{43}\end{array}$ & $\begin{array}{l}\text { Indi } \\
\mathrm{a}\end{array}$ & $\begin{array}{l}\text { Clinic } \\
\text { al } \\
\text { study }\end{array}$ & $\begin{array}{l}\text { Non- } \\
\text { rando } \\
\mathrm{m}\end{array}$ & $30 / 30$ & 37 years & - & $\begin{array}{l}\text { Sympt } \\
\text { omatic } \\
\text { mandi } \\
\text { bular } \\
\text { first } \\
\text { molar }\end{array}$ & $\begin{array}{l}\text { Cold } \\
\text { testin } \\
\mathrm{g} \\
\text { with } \\
\text { an } \\
\text { ice } \\
\text { stick } \\
\\
\text { Elect } \\
\text { ric } \\
\text { pulp } \\
\text { tester }\end{array}$ & $\mathrm{No} /-$ & $\begin{array}{l}4 \% \\
\text { Artica } \\
\text { ine } \\
\text { with } \\
1: 2,0 \\
0,000 \\
\text { adren } \\
\text { aline }\end{array}$ & $\begin{array}{l}2 \% \\
\text { Ligno } \\
\text { caine } \\
\text { with } \\
1: 2,00 \\
, 000\end{array}$ & $\begin{array}{l}\text { BI } \\
\text { injectio } \\
n\end{array}$ & IANB & 1.7 & 1.7 & 15 & $\begin{array}{l}\text { Aestheti } \\
\mathrm{c} \\
\text { success }\end{array}$ & $\begin{array}{l}4 \% \\
\text { Articaine } \\
\text { with } \\
1: 1,00,00 \\
0 \\
\text { adrenaline } \\
\text { can be } \\
\text { considere } \\
\text { d as an } \\
\text { alternativ } \\
\text { e for } \\
\text { anesthetis }\end{array}$ \\
\hline
\end{tabular}




\begin{tabular}{|c|c|c|c|c|c|c|c|c|c|c|c|c|c|c|c|c|c|c|}
\hline & & & & & & & & & & & & & & & & & & $\begin{array}{l}\text { ing } \\
\text { mandibul } \\
\text { ar first } \\
\text { molar } \\
\text { instead of } \\
\text { IANB } \\
\text { with } 2 \% \\
\text { lignocaine } \\
\text { with } \\
1: 2,00,00 \\
0 \\
\text { adrenaline }\end{array}$ \\
\hline $\begin{array}{l}\text { Agg } \\
\text { arwa } \\
1 \mathrm{~V} \\
\text { et al } \\
(201 \\
1)^{44}\end{array}$ & $\begin{array}{l}\text { Indi } \\
\mathrm{a}\end{array}$ & $\begin{array}{l}\text { Prosp } \\
\text { ective } \\
\text { rando } \\
\text { mized } \\
\text { doubl } \\
\text { e- } \\
\text { blind } \\
\text { study }\end{array}$ & $\begin{array}{l}\text { Simpl } \\
\text { e } \\
\text { rando } \\
\text { m } \\
\text { genera } \\
\text { tor }\end{array}$ & $24 / 24$ & $\begin{array}{l}31 / \\
30.4\end{array}$ & $\begin{array}{l}11 \mathrm{M}, 13 \\
\mathrm{~F} / \\
12 \mathrm{M}, 11 \\
\mathrm{~F}\end{array}$ & $\begin{array}{l}\text { Mandi } \\
\text { bular } \\
\text { molar }\end{array}$ & $\begin{array}{l}\text { Cold } \\
\text { testin } \\
\mathrm{g} \\
\text { with } \\
\text { an } \\
\text { ice } \\
\text { stick } \\
\text { and } \\
\text { an } \\
\text { electr } \\
\text { ic } \\
\text { pulp } \\
\text { tester }\end{array}$ & $\begin{array}{l}\mathrm{No} / \mathrm{Ye} \\
\mathrm{s}\end{array}$ & $\begin{array}{l}4 \% \\
\text { Artica } \\
\text { ine } \\
\text { with } \\
1: 100 \\
, 000 \\
\text { ephin } \\
\text { ephri } \\
\text { ne }\end{array}$ & $\begin{array}{l}\% \\
\text { Lidoc } \\
\text { aine } \\
\text { with } \\
1: 200, \\
000 \\
\text { epinep } \\
\text { hrine }\end{array}$ & $\begin{array}{l}\text { IANB } \\
\text { plus } \\
\text { BI }\end{array}$ & $\begin{array}{l}\text { IANB } \\
\text { injectio } \\
\text { ns }\end{array}$ & $\begin{array}{l}\text { Stand } \\
\text { ard } \\
4 \% \\
\text { Artica } \\
\text { ine } \\
\text { cartri } \\
\text { dge }\end{array}$ & 1.8 & 15 & $\begin{array}{l}\text { Pre- } \\
\text { post- } \\
\text { operativ } \\
\text { e pain } \\
\text { Success } \\
\text { of } \\
\text { anaesthe } \\
\text { sia }\end{array}$ & $\begin{array}{l}\text { Suppleme } \\
\text { ntal } \\
\text { infiltratio } \\
\text { ns of } \\
\text { Articaine } \\
\text { along } \\
\text { with } \\
\text { conventio } \\
\text { nal IANB, } \\
\text { can be a } \\
\text { useful } \\
\text { adjunct in } \\
\text { managem } \\
\text { ent of } \\
\text { odontoge } \\
\text { nic pain } \\
\text { in } \\
\text { irreversibl } \\
\text { e pulpitis }\end{array}$ \\
\hline $\begin{array}{l}\text { Poor } \\
\text { ni S } \\
\text { et al } \\
(201 \\
1)^{45}\end{array}$ & $\begin{array}{l}\text { Indi } \\
\mathrm{a}\end{array}$ & $\begin{array}{l}\text { Rand } \\
\text { omize } \\
\text { d } \\
\text { doubl } \\
\text { e- } \\
\text { blind } \\
\text { clinic } \\
\text { al } \\
\text { trial }\end{array}$ & $\begin{array}{l}\text { Simpl } \\
\text { e } \\
\text { rando } \\
\text { mizati } \\
\text { on }\end{array}$ & $\begin{array}{l}\text { Test arm } \\
\text { A } \\
52 \\
\text { Test arm } \\
\text { B } \\
52 \\
\text { Test arm } \\
\text { C } \\
52\end{array}$ & $\begin{array}{l}\text { Test arm } \\
\text { A } \\
24.40 \\
(4.19) \\
\\
\text { Test arm } \\
\text { B } \\
23.46(3.7) \\
\\
\text { Test arm } \\
\text { C } \\
24.13(4.2 \\
1)\end{array}$ & $\begin{array}{l}\text { Test arm } \\
\text { A } \\
28 \mathrm{M} 24 \mathrm{~F} \\
\text { Test arm } \\
\text { B } \\
30 \mathrm{M}, 32 \\
\mathrm{~F} \\
\\
\text { Test arm } \\
\text { C } \\
32 \mathrm{M}, 20 \\
\mathrm{~F}\end{array}$ & $\begin{array}{l}\text { Sympt } \\
\text { omatic } \\
\text { Mandi } \\
\text { bular } \\
\text { molars }\end{array}$ & $\begin{array}{l}\text { Cold } \\
\text { testin } \\
\mathrm{g} \\
\text { with } \\
\text { an } \\
\text { ice } \\
\text { stick } \\
\\
\text { Elect } \\
\text { ric } \\
\text { pulp } \\
\text { tester }\end{array}$ & $\begin{array}{l}\mathrm{No} / \mathrm{Ye} \\
\mathrm{s}\end{array}$ & $\begin{array}{l}\% \\
\text { Artica } \\
\text { ine } \\
\text { with } \\
1: 100 \\
, 000 \\
\text { epine } \\
\text { phrin } \\
\text { e }\end{array}$ & $\begin{array}{l}2 \% \\
\text { Lidoc } \\
\text { aine } \\
\text { with } \\
1: 100 \text {, } \\
000\end{array}$ & $\begin{array}{l}\text { Test } \\
\text { arm A } \\
\text { IANB } \\
\text { with } \\
4 \% \\
\text { Articai } \\
\text { ne } \\
\\
\text { Test } \\
\text { arm B } \\
\text { BI with } \\
4 \% \\
\text { Articai } \\
\text { ne }\end{array}$ & $\begin{array}{l}\text { Test } \\
\text { arm C } \\
\text { IANB } \\
\text { with } \\
4 \% \\
\text { Lidocai } \\
\text { ne }\end{array}$ & 1.8 & 1.8 & 20 & $\begin{array}{l}\text { Success } \\
\text { ful } \\
\text { anaesthe } \\
\text { sia }\end{array}$ & $\begin{array}{l}\text { There is } \\
\text { no } \\
\text { statisticall } \\
\mathrm{y} \\
\text { significan } \\
\mathrm{t} \\
\text { difference } \\
\text { among } \\
\text { IANB and } \\
\text { infiltratio } \\
\mathrm{n} \text { of } \\
\text { Articaine } \\
\text { when } \\
\text { compared } \\
\text { with } \\
\text { IANB of } \\
\text { lidocaine } \\
\text { in }\end{array}$ \\
\hline
\end{tabular}




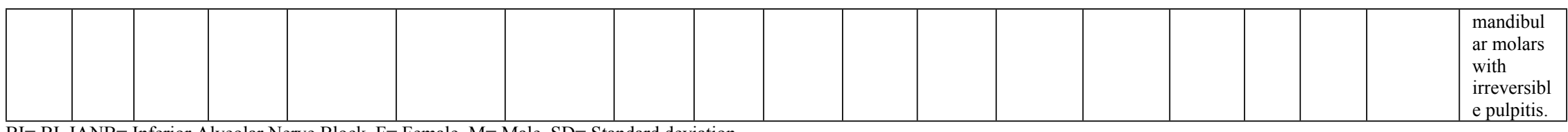




\section{Table 3 (on next page)}

Methodological index for non-randomized studies (MINORS)

Methodological index for non-randomized studies (MINORS) 
Table 3- Methodological index for non-randomized studies (MINORS)

\begin{tabular}{|c|c|c|c|c|c|c|c|c|c|c|c|c|c|}
\hline & $\begin{array}{c}\text { A } \\
\text { clea } \\
\text { rly } \\
\text { state } \\
\text { d } \\
\text { aim }\end{array}$ & $\begin{array}{c}\text { Inclusi } \\
\text { on of } \\
\text { consec } \\
\text { utive } \\
\text { patient } \\
\text { s }\end{array}$ & $\begin{array}{c}\text { Prospect } \\
\text { ive } \\
\text { collectio } \\
\text { n of } \\
\text { data }\end{array}$ & $\begin{array}{l}\text { Endpoin } \\
\text { ts } \\
\text { appropri } \\
\text { ate to } \\
\text { the aim } \\
\text { of the } \\
\text { study }\end{array}$ & $\begin{array}{l}\text { Unbiase } \\
\text { d } \\
\text { assessm } \\
\text { ent of } \\
\text { the } \\
\text { study } \\
\text { endpoin } \\
t\end{array}$ & $\begin{array}{l}\text { Follow } \\
\text {-up } \\
\text { period } \\
\text { approp } \\
\text { riate to } \\
\text { the } \\
\text { aim of } \\
\text { the } \\
\text { study }\end{array}$ & $\begin{array}{l}\text { Loss } \\
\text { to } \\
\text { follo } \\
\text { w } \\
\text { up } \\
\text { less } \\
\text { than } \\
5 \%\end{array}$ & $\begin{array}{l}\text { Prospe } \\
\text { ctive } \\
\text { calculat } \\
\text { ion of } \\
\text { the } \\
\text { study } \\
\text { size }\end{array}$ & $\begin{array}{c}\text { *An } \\
\text { adequat } \\
\text { e control } \\
\text { group }\end{array}$ & $\begin{array}{c}\text { *Conte } \\
\text { mporar } \\
\mathbf{y} \\
\text { groups }\end{array}$ & $\begin{array}{c}\text { *Baseli } \\
\text { ne } \\
\text { equival } \\
\text { ence of } \\
\text { groups }\end{array}$ & $\begin{array}{c}{ }^{*} \text { Ade } \\
\text { quate } \\
\text { statis } \\
\text { tical } \\
\text { analy } \\
\text { ses }\end{array}$ & $\begin{array}{c}\text { Tota } \\
1\end{array}$ \\
\hline $\begin{array}{l}\text { Ahma } \\
d \text { ZH } \\
\text { et al } \\
(2014) \\
35\end{array}$ & 2 & 2 & 2 & 2 & 1 & 2 & 2 & 0 & 2 & 2 & 2 & 2 & 21 \\
\hline $\begin{array}{l}\text { Subbiy } \\
\text { a A et } \\
\text { al } \\
(2012) \\
43\end{array}$ & 2 & 2 & 2 & 2 & 1 & 2 & 2 & 0 & 2 & 2 & 2 & 2 & 21 \\
\hline
\end{tabular}

$3 \uparrow$ The items are scored 0 (not reported), 1 (reported but inadequate) or 2 (reported and adequate). The global ideal score being 16 for 4 non-comparative studies and 24 for comparative studies.

$5 \quad$ *For study with control group 


\section{Table 4(on next page)}

Sensitivity and subgroup analysis of the outcomes between articaine and lidocaine group in tooth unit for mandibular region

Sensitivity and subgroup analysis of the outcomes between articaine and lidocaine group in tooth unit for mandibular region 
1 Table 4- Sensitivity and subgroup analysis of the outcomes between articaine and lidocaine 2 group in tooth unit for mandibular region

\begin{tabular}{|l|l|}
\hline \multicolumn{1}{|c|}{ Item } & Success of local anaesthesia (RR, 95\% CI) \\
\hline Original estimates & $1.37[1.17,1.62], \mathrm{P}=0.0002$ \\
\hline $\begin{array}{l}\text { Exclusion all the studies of } \\
\text { high risk of bias }\end{array}$ & $1.28[1.09,1.52], \mathrm{P}=0.003$ \\
\hline $\begin{array}{l}\text { Exclusion all the studies of } \\
\text { moderate risk of bias }\end{array}$ & $1.41[1.17,1.70], \mathrm{P}=0.0003$ \\
\hline $\begin{array}{l}\text { Exclusion all the studies of } \\
\text { low risk of bias }\end{array}$ & $1.58[1.12,2.24], \mathrm{P}=0.003$ \\
\hline $\begin{array}{l}\text { Inclusion of studies of } \\
\text { low risk of bias only }\end{array}$ & $1.31[1.08,1.60], \mathrm{P}=0.003$ \\
\hline Fixed or random effects & $1.37[1.26,1.49], \mathrm{P}<0.00001$ \\
\hline Fixed effect & $1.37[1.17,1.62], \mathrm{P}=0.0002$ \\
\hline Random effect & $1.30[1.19,1.41], \mathrm{P}=0.001$ \\
\hline Exclusion of subgroups with single study & $1.25[0.98,1.59], \mathrm{P}=0.07$ \\
\hline Inclusion of IANB only & $1.13[0.89,1.45], \mathrm{P}=0.31$ \\
\hline $\begin{array}{l}\text { Inclusion of buccal infiltration } \\
\text { Only }\end{array}$ & $1.53[1.21,1.94], \mathrm{P}=0.0004$ \\
\hline $\begin{array}{l}\text { Inclusion of supplementary buccal } \\
\text { infiltration after IANB failure } \\
\text { Only }\end{array}$ & \\
\hline
\end{tabular}

4 CI- Confidence interval, IANB- Inferior alveolar nerve block, RR- Relative risk 